OPEN ACCESS

Edited by:

Lucienne Chatenoud,

Université Paris Descartes, France

Reviewed by:

Mark Larché

McMaster University, Canada

Eliane Piaggio,

Immunity and Cancer (INSERM),

France

*Correspondence:

Leonardo Fainboim

Ifainboim@hospitaldeclinicas.uba.ar

Specialty section:

This article was submitted to Immunological Tolerance and

Regulation,

a section of the journal

Frontiers in Immunology

Received: 16 April 2018 Accepted: 12 November 2018 Published: 29 November 2018

Citation:

Machicote A, Belén S, Baz P, Billordo LA and Fainboim L (2018) Human $C D 8^{+} H L A-D R^{+}$Regulatory $T$

Cells, Similarly to Classical

$\mathrm{CD}^{+}{ }^{+} \mathrm{Foxp3}^{+}$Cells, Suppress Immune Responses via PD-1/PD-L1

Axis. Front. Immunol. 9:2788.

doi: 10.3389/fimmu.2018.02788

\section{Human $\mathrm{CD8}^{+} \mathrm{HLA}^{-\mathrm{DR}^{+}}$Regulatory $\mathrm{T}$ Cells, Similarly to Classical CD4 ${ }^{+}$Foxp3 ${ }^{+}$Cells, Suppress Immune Responses via PD-1/PD-L1 Axis}

\author{
Andres Machicote ${ }^{1}$, Santiago Belén ${ }^{1}$, Placida Baz ${ }^{1}$, Luis A. Billordo ${ }^{1}$ and \\ Leonardo Fainboim ${ }^{1,2 *}$
}

${ }^{1}$ Laboratorio de Inmunogenética, Facultad de Farmacia y Bioquímica, Instituto de Inmunología, Genética y Metabolismo, Universidad de Buenos Aires-Consejo Nacional de Investigaciones Científicas y Técnicas, Buenos Aires, Argentina,

${ }^{2}$ Departamento de Microbiología, Parasitología e Inmunología, Facultad de Medicina, Universidad de Buenos Aires, Buenos Aires, Argentina

We have previously identified a human $\mathrm{CD}^{+} \mathrm{HLA}-\mathrm{DR}{ }^{+}$regulatory $\mathrm{T}$ cell subset with the ability to suppress proliferation of autologous PBMCs responder cells through cell contact and CTLA-4 co-inhibitory molecule. The present study characterizes the complete phenotype of $\mathrm{CD}^{+} \mathrm{HLA}-\mathrm{DR}^{+}$Treg cells which showed great similarities with classical $\mathrm{CD}^{+}{ }^{+}$cells expressing forkhead box P3 (FOXP3). The shared features included the expression of programmed cell death protein 1 (PD-1), T-cell immunoreceptor with Ig and ITIM domains (TIGIT), C-C chemokine receptor type 4 and 5 (CCR4 and CCR5), low expression of CD127, and a memory and effector-like phenotype. CD8 ${ }^{+} \mathrm{HLA}-\mathrm{DR}{ }^{+}$ Treg-induced suppression on $\mathrm{CD}^{+}{ }^{+}$responder $\mathrm{T}$ cells was abrogated by an anti-PD1 neutralizing antibody. Anti-PD-1 did not abrogate the suppressor effect induced on responder $\mathrm{CD}^{+}{ }^{+} \mathrm{T}$ cells. In addition, $\mathrm{CD} 8^{+} \mathrm{HLA}-\mathrm{DR}^{+}$Treg induced a preferential death on responder $\mathrm{CD}^{+} \mathrm{T}$ cells. This effect was not reversed by PD-1 neutralization. After activation, most $\mathrm{CD} 8^{+} \mathrm{HLA}-\mathrm{DR}^{+}$Treg acquire programmed death-ligand 1 (PD-L1) expression. Interestingly, PD-L1 may induce apoptosis through CD80 expressed on activated $\mathrm{CD}^{+}$responder $\mathrm{T}$ cells. After PBMCs stimulation, CD8 ${ }^{+} \mathrm{HLA}-\mathrm{DR}{ }^{+}$Treg cells showed an increased frequency of IFN- $\gamma$ and TNF $\alpha$ positive cells and higher degranulation. These data strongly argue against $\mathrm{CD} 8^{+} \mathrm{HLA}-\mathrm{DR}^{+}$Treg being exhausted cells. Overall, the data presented in this study indicate that $\mathrm{CD} 8^{+} \mathrm{HLA}-\mathrm{DR}{ }^{+}$Treg and CD4 ${ }^{+}$FOXP3 ${ }^{+}$Treg share phenotypic and functional features, which may provide cues to similar involvements in the control of antitumor immune responses and autoimmunity.

Keywords: CD8 ${ }^{+}$HLA-DR $^{+}$, PD-1/PD-L1, TIGIT, CCR4, CD127, regulatory T cells, anti-PD-1 


\section{INTRODUCTION}

Regulatory T cells (Treg) play a key role in maintaining immune homeostasis and in preventing the onset of autoimmune diseases (1). Although several subsets of Treg have been described, the best characterized is defined by expression of CD4, CD25, and the transcription factor forkhead box P3 (FOXP3) (2). Most circulating $\mathrm{CD}^{+}{ }^{+} \mathrm{FOXP}^{+}$Treg originate in the thymus (tTreg). However, naïve $\mathrm{CD}^{+}{ }^{+} \mathrm{T}$ cells may also be induced to express FOXP3 in the periphery, representing a minority (pTreg) population (3) required for fetal tolerance (4).

We recently described a novel human regulatory $\mathrm{CD} 8^{+} \mathrm{HLA}-$ $\mathrm{DR}^{+} \mathrm{T}$ cell population present in adult and umbilical venous blood samples (5) representing a small subset in peripheral blood (PB) or cord blood mononuclear cells (CBMCs). The comparison between $\mathrm{CD}^{+} \mathrm{HLA}^{-\mathrm{DR}^{-}}$and $\mathrm{CD}^{+}{ }^{+} \mathrm{HLA}_{-} \mathrm{DR}^{+} \mathrm{T}$ cells shows similar expression of the costimulatory molecule CD28, which differentiates them from the previously characterized $\mathrm{CD} 8^{+} \mathrm{CD} 28^{-/ \text {low }} \mathrm{T}$ suppressor cells originally generated in vitro by multiple rounds of $\mathrm{T}$ cell stimulation by allogenic APCs (6). Another natural $\mathrm{CD}^{+}$Treg population distinguished by expression of CD122 (7) was described in mice, but has not yet been identified in humans, and appear to exert their suppressor effect via IL-10.

The presence of $\mathrm{CD}^{+} \mathrm{HLA}^{-\mathrm{DR}^{+}}$Treg in cord blood strongly suggests that these Treg most likely originate from thymic emigrants and gradually increase over time. Their expansion is presumably induced through an encounter with environmental or self-antigens that generate the memory-like phenotype observed in adult $\mathrm{CD}^{+} \mathrm{HLA}^{-\mathrm{DR}^{+}}$ Treg.

In the control of peripheral T-cell tolerance and autoimmunity, checkpoint pathways involving particularly cytotoxic T-lymphocyte-associated antigen 4 (CTLA-4) and programmed death 1 (PD-1) are thought to operate at different stages of an immune response (8), CTLA- 4 acting at the initial stage of naïve T-cell activation, typically in lymph nodes (9). PD-1 pathway regulates previously activated $\mathrm{T}$ cells at later stages of immune response, primarily in peripheral tissues (8). Similarities and differences in these pathways have greatly contributed to cancer therapy involving immune checkpoint blockade (ICB).

In our previous study we identified features shared between $\mathrm{CD}^{+}{ }^{+} \mathrm{HLA}_{-} \mathrm{DR}^{+}$Treg and classical $\mathrm{CD} 4^{+}{ }^{+} \mathrm{FOXP} 3^{+}$Treg cells; these included the requirement for cell-to-cell contact mainly involving CTLA-4, and complete abrogation of suppressor capacity by blocking this B7 ligand. In the present study we expanded phenotypic and functional characterization of CD ${ }^{+}{ }^{+} \mathrm{LLA}-\mathrm{DR}^{+}$Treg cells, including the complete phenotype of the $\mathrm{CD}^{+} \mathrm{HLA}^{-\mathrm{DR}^{+}}$Treg cells, their developmental stage, their exhaustion status, and similarities with canonical $\mathrm{CD}^{+}{ }^{+} \mathrm{FOXP}^{+}$Treg cells. In addition, we demonstrated that anti-PD-1 selectively abrogates the suppressor effect on $\mathrm{CD}^{+}$effector cells without affecting $\mathrm{CD}^{+}$effector cells.

\section{MATERIALS AND METHODS}

\section{Ethics Statement}

This study was approved by the Investigation and Ethics Committee at the Hospital de Clínicas "Jose' de San Martin” and Hospital de Pediatría S.A.M.I.C. "Prof. Dr. Juan P. Garrahan” in accordance with the Declaration of Helsinki.

\section{Subjects}

Peripheral blood (PB) mononuclear cells were obtained from healthy adult donors (HD), and cord blood (CB) samples from umbilical cord veins of full-term healthy neonates. None of the HD, neonates, or their mothers had any hereditary disorders, hematologic abnormalities, or infectious complications.

\section{Peripheral Blood and Cord Blood Mononuclear Cell Isolation}

Freshly isolated PBMCs or CB mononuclear cells were isolated through Ficoll-Hypaque gradient centrifugation (GE Healthcare Life Sciences). After two washes with PBS, cells were suspended in RPMI medium.

\section{Antibodies, Flow Cytometry, and Analysis of Cytokine Production}

Isolated peripheral and cord blood mononuclear cells were incubated for $15 \mathrm{~min}$ at room temperature (RT) with fluorescence-conjugated mAbs purchased from the following sources: Biolegend: anti-CD3 (PerCP or Pacific Blue), anti-CD8 (APC-Cy7 or PerCP), anti-HLA-DR (FITC, PE or Brilliant Violet 421), anti-CD45RA (PE-Cy7), anti-CD27 (PE-Texas Red), anti-CD28 (PE or Brilliant Violet 711), anti-CCR7 (FITC or Brilliant Violet 785), anti-CCR5 (PE-Cy7), anti-CXCR3 (FITC), anti-CCR4 (Brilliant Violet 421), anti-PD-1 (PE or Brilliant Violet 711), anti-PD-L1 (APC), anti-CD155 (PECy7), anti-Eomes (PE-Cy7), anti-CD127 (PE), anti-IFN- $\gamma$ (PE-Cy7), anti-TNF $\alpha$ (Brilliant Violet 711), anti-CD107a (PE or FITC), anti-Ki-67 (PE or FITC). eBiosciences: anti-TIM-3 (APC), anti-CTLA-4 (PE), anti-TIGIT (PerCPeFluor710). Immunotools: anti-CD8 (APC), anti-HLA-DR (PE), antiGranzyme B (FITC). For intranuclear staining, PBMCs were fixed and permeabilized with FOXP3 / Transcription Factor Fixation/Permeabilization Concentrate and Diluent solution (eBioscience) following the manufacturer's instructions. AntiKi-67 Ab was incubated after permeabilization. To detect intracellular cytokines, PBMCs were activated with PMA $(50 \mathrm{ng} / \mathrm{mL})$ and Ionomycin $(1 \mu \mathrm{g} / \mathrm{mL})$ for $4 \mathrm{~h}$ in the presence of monensin (Golgi stop-BD Biosciences). Alternatively, PBMCs were activated with plate-coated anti-CD3 $(1 \mu \mathrm{g} / \mathrm{mL})$ and soluble anti-CD28 $(1 \mu \mathrm{g} / \mathrm{mL})$. Anti-CD107a was added during in vitro stimulation to detect degranulation. After permeabilization using the $\mathrm{BD}$ Cytofix/Cytoperm Fixation/Permeabilization Kit (BD Biosciences), anti-IFN- $\gamma$, anti-TNF $\alpha$, anti-CTLA-4, and anti-Granzyme $B$ were added. LIVE/DEAD ${ }^{\circledR}$ Fixable Aqua (Thermofisher) or 7AAD (BD Biosciences) were used to exclude dead cells. The gating strategy is depicted in Figure S1. Flow cytometry was performed using FACS 
Aria $\mathrm{II}^{\mathrm{u}}$ (BD Biosciences), and data analyzed using FlowJo software.

\section{Cell Sorting}

Fresh peripheral blood $\mathrm{CD} 8^{+} \mathrm{T}$ cells from healthy donors were enriched by negative selection using the RosetteSep Human $\mathrm{CD}^{+} \mathrm{T}$ Cells Enrichment Cocktail (StemCell Technologies) following manufacturer's protocol. Purified CD8 ${ }^{+} \mathrm{T}$ cells were stained with anti-CD8 APC and anti-HLA-DR PE antibodies (Immunotools) and sorted with a FACS Aria $\mathrm{II}^{\mathrm{u}}$ flow cytometer (BD Biosciences), obtaining the following subsets: $\mathrm{CD} 8^{+} \mathrm{HLA}-$ $\mathrm{DR}^{+}$and $\mathrm{CD}^{+} \mathrm{HLA}^{-} \mathrm{DR}^{-}$. Both subsets were collected into complete RPMI 1640 medium containing 50\% FCS and washed before further experiments. The purity of each population, determined by flow cytometry, was always over 95\%. For $\mathrm{CD}^{+}$cells depletion, peripheral blood mononuclear cells from healthy donors were isolated by density gradient, and $\mathrm{CD}^{+}$lymphocytes were depleted after staining with anti-CD8 APC (Immunotools). $\mathrm{CD}^{+}$depletion was $\sim 99 \%$ effective.

\section{Suppression Assay}

Responder autologous PBMCs were labeled with $5 \mu \mathrm{M}$ of CellTrace Violet (ThermoFisher) following manufacturer's protocol. $5 \times 10^{4}$ responder cells were plated on 96 roundbottom wells and co-cultured in complete RPMI 1640 medium [Life Technologies] (supplemented with penicillin, streptomycin, L-glutamine [Sigma-Aldrich], and 10\% FCS [Natocor]) with unlabeled highly purified $\mathrm{CD} 8^{+} \mathrm{HLA}^{-\mathrm{DR}}{ }^{+}$or $\mathrm{CD} 8^{+} \mathrm{HLA}-\mathrm{DR}-$ $\mathrm{T}$ cells in a responder: suppressor ratio of $1: 1$. Cells were stimulated with $1 \mu \mathrm{g} / \mathrm{mL}$ of plate-coated CD3 (Biolegend) and $1 \mu \mathrm{g} / \mathrm{mL}$ of soluble CD28 (Biolegend). On day 4 postactivation, cells were harvested, and proliferation of CellTrace Violet-labeled cells was assessed by flow cytometry. At this time point, cells were stained with anti-human CD3 FITC (Immunotools), anti-human CD4 BV605 (Biolegend) and anti-human CD8 APC (Immunotools), and incubated with 7-AAD (BD Bioscience) to analyze cytotoxicity and exclude dead cells. Percentage of suppression was calculated by dividing the number of proliferating CellTrace Violet-diluting responder cells in the presence of suppressor cells by the number of proliferating responder cells when cultured alone, multiplied by 100. Unlabeled, stimulated, and unstimulated cells were used as controls.

\section{Neutralizing Assay}

To investigate neutralizing the suppressor effect, purified anti-PD- 1 antibody $(0.5$ and $1 \mu \mathrm{g} / \mathrm{mL}$; Biolegend $)$ was added in the same culture conditions described for the suppression assay above, using the corresponding isotypematched $\mathrm{mAb}$ as control. Purified PD-L1 neutralizing antibody (Biolegend) was used at $5 \mu \mathrm{g} / \mathrm{mL}$. To test involvement of CTLA-4 added together with anti-PD-1 in the suppression mechanism, $5 \mu \mathrm{g} / \mathrm{mL}$ of anti-CTLA-4 (BD Biosciences) was used.

\section{Co-culture of CD8 ${ }^{+}$-Depleted PBMCs With Highly Purified CD8 ${ }^{+}$HLA-DR $^{-}$or $\mathrm{CD8}^{+} \mathrm{HLA}^{-\mathrm{DR}^{+}}$Cells}

Autologous $5 \times 10^{5} \mathrm{CD}^{+}$-depleted PBMCs were plated on 48 multiwell plates in complete RPMI medium, and co-cultured with highly purified $0.9 \times 10^{5} \mathrm{CD}^{+} \mathrm{HLA}_{-\mathrm{DR}}^{-}$(5.5: 1), or $0.1 \times 10^{5} \mathrm{CD}^{+} \mathrm{HLA}^{-\mathrm{DR}^{+}}$(50: 1) $\mathrm{T}$ cells (the number of cells were defined according to their relative frequencies within PBMCs). Cells were activated with plate-coated aCD3 $(1 \mu \mathrm{g} / \mathrm{mL}$; Biolegend) plus soluble aCD28 ( $1 \mu \mathrm{g} / \mathrm{mL}$; Biolegend). On day 4 post-activation, cells were harvested, and surface HLA-DR and intra-cellular Ki-67 were assessed by flow cytometry. Dead cells were excluded using LIVE/DEAD ${ }^{\circledR}$ Fixable Aqua (Thermofisher). Unstimulated cultures were used as negative controls.

\section{Activation of PBMCs and CBMC}

Peripheral Blood (PB) or Cord Blood (CB) mononuclear cells were activated with plate-coated anti-CD3 $(1 \mu \mathrm{g} / \mathrm{mL})$ plus soluble anti-CD28 $(1 \mu \mathrm{g} / \mathrm{mL})$. In both cases, $5 \times 10^{5}$ cells were plated on 48 multiwell plates in complete RPMI medium. For PBMCs kinetics experiments, cells were stained on day 4 after activation. For CB samples, cells were stained on day 2 after activation.

\section{Statistical Analysis}

The normality of variable distribution was assessed by the Kolmogorov- Smirnov goodness-of-fit test. Once the hypothesis of normality was accepted $(p=0.05)$, comparisons were performed using paired and unpaired Student $t$-tests, as appropriate. If the hypothesis of normality was rejected, analysis was performed using Wilcoxon's rank-sum test. A p-value of 0.05 was considered significant.

\section{RESULTS}

\section{CD8 $^{+}$T Cells Expressing HLA-DR Identified Regulatory T Cells Expressing the Checkpoint Molecules CTLA-4 and PD-1}

We first analyzed phenotypic markers previously associated with regulatory subsets. For instance, $\mathrm{PD}-1$ and TIGIT are known to be expressed in classical FOXP3 ${ }^{+}$Treg (10-12), the IL7 receptor (CD127) is broadly used to isolate $\mathrm{CD}^{+}{ }^{+} \mathrm{FOXP} 3^{+}$ Treg, and CXCR3, CCR5, and CCR4 are present in Treg cells in peripheral tissues: $\mathrm{CD} 4{ }^{+} \mathrm{CD} 25^{+} \mathrm{FOXP}^{+}(13,14)$, and $\mathrm{CD} 4^{+} \operatorname{Tr}^{+}(15,16)$. Considering that HLA-DR is used as an activation marker, we also analyzed TIM-3 and PD-L1

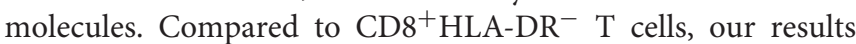
showed a higher frequency of PD-1 $(p<0.0001)$ and TIGIT $(p<0.0001)$, and down-modulation of CD127 frequency $(p$ $=0.0009$ ) (Figures 1A,B). In addition to increased frequency, PD-1 expression was also significantly higher $(p=0.0003)$ as reflected by increased mean fluorescence intensity (MFI). CD127 MFI was also lower in $\mathrm{CD}^{+} \mathrm{HLA}^{-\mathrm{DR}^{+}}$Treg than in $\mathrm{CD}^{+} \mathrm{HLA}^{-\mathrm{DR}}{ }^{-}$cells $(p=0.0031)$ (Figure 1C). Interestingly, the frequencies of CCR5 $(p<0.0001)$ and CCR4 $(p=$ 
A

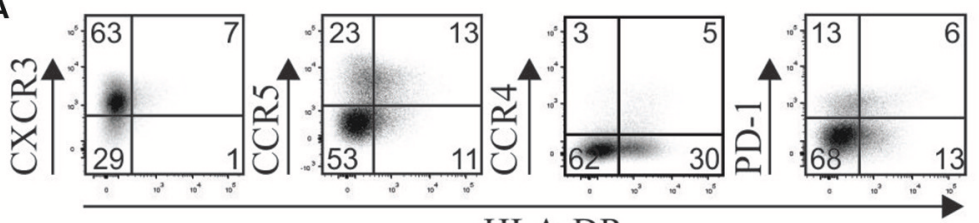

HLA-DR
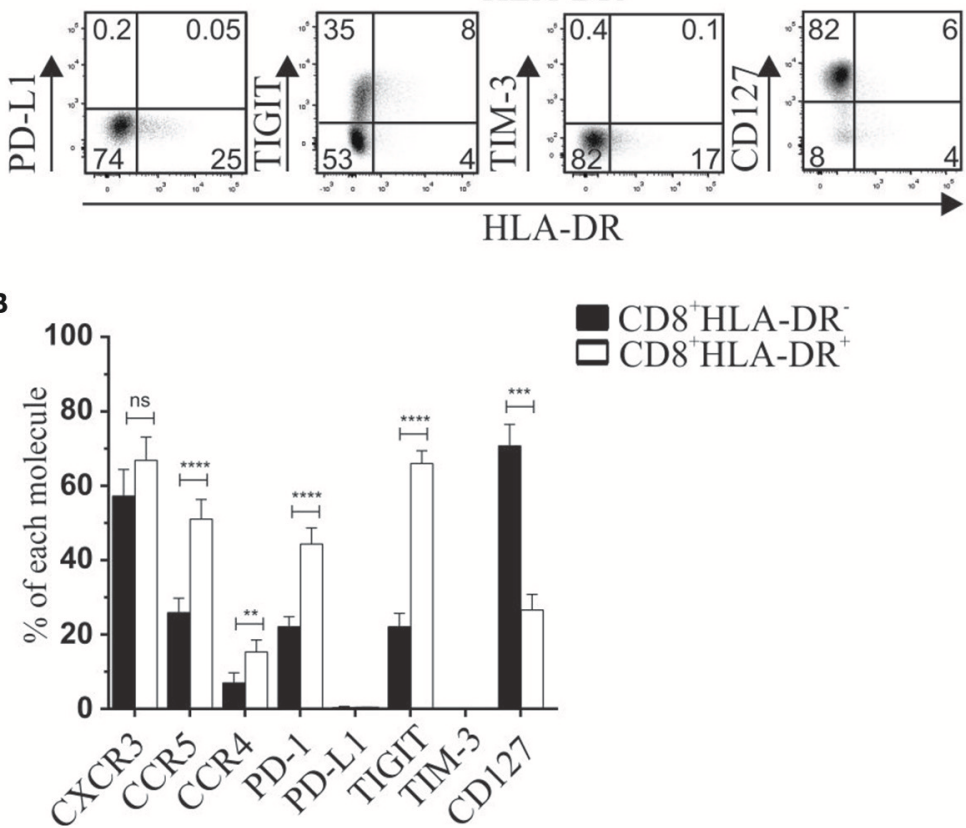

C

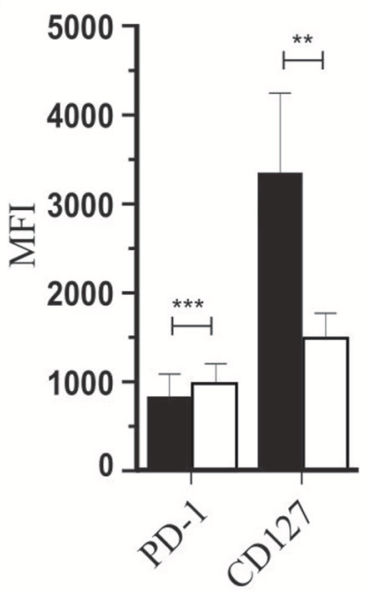

FIGURE 1 | Phenotypic characterization of $\mathrm{CD}^{+} \mathrm{HLA}^{-\mathrm{DR}^{+}}$Treg and $\mathrm{CD} 8^{+} \mathrm{HLA}-\mathrm{DR}{ }^{-}$cells. (A) PBMC from healthy donors were isolated by density gradient, stained, and analyzed by flow cytometry. Dot plots are gated on total CD8 ${ }^{+} \mathrm{T}$ cells. (B) Graph shows comparative frequency of each molecule gated on CD8 ${ }^{+} \mathrm{HLA-DR}{ }^{-}$and $\mathrm{CD}^{+} \mathrm{HLA}^{-\mathrm{DR}^{+}}$subsets. (C) Mean fluorescence intensity (MFI) of PD-1 and CD127 expression. Data is presented as mean \pm SEM of PD-1 $(n=17)$, CXCR3 $(n=5)$, CCR5 $(n=15)$, CCR4 $(n=7)$, PD-L1 $(n=5)$, TIGIT $(n=13)$, TIM-3 $(n=5)$, CD127 $(n=6)$. Paired $t$-test. ${ }^{* \star} p<0.01 ;{ }^{* \star *} p<0.001 ;{ }^{* \star * *} p<0.0001$.

0.0038), were greatly increased in $\mathrm{CD}^{+} \mathrm{HLA}^{-\mathrm{DR}^{+}}$Treg cells (Figures 1A,B).

\section{Naïve Cord Blood CD8 ${ }^{+}$HLA-DR $^{+}$T Cells Rapidly Acquired the Phenotype of Mature Peripheral Blood CD8 ${ }^{+}$HLA-DR $^{+}$Treg Cells After Activation}

In basal conditions, cord blood (CB) $\mathrm{CD}^{+} \mathrm{HLA}^{-} \mathrm{DR}^{-}$and $\mathrm{CD}^{+}{ }^{+} \mathrm{HLA}_{-\mathrm{DR}}{ }^{+}$subsets showed a naïve phenotype, with low frequency of PD-1, TIGIT, and CTLA-4 ( $<10 \%)$, and more than $90 \%$ of cells from both subsets expressed the CD127 receptor (Figures 2A,B). Despite these similarities, compared to their $\mathrm{CD}^{+} \mathrm{HLA}^{-\mathrm{DR}^{-}}$counterpart, $\mathrm{CD} 8^{+} \mathrm{HLA}_{-} \mathrm{DR}^{+}$Treg showed a slightly but significantly increased number of cells expressing PD-1 $(p=0.0079)$, TIGIT $(p=0.0079)$, and CTLA-4 ( $p=0.0003)$ (Figure 2B). Because we previously observed that cord blood $\mathrm{CD}^{+} \mathrm{HLA}^{-\mathrm{DR}^{+}}$Treg were able to suppress responder cell proliferation, we analyzed the expression kinetics of relevant molecules for suppression after activation by anti-CD3 plus anti-CD28 antibodies. As depicted in Figures 2B,C, as soon as 2 days after activation, CB
$\mathrm{CD}^{+}{ }^{+} \mathrm{HLA}-\mathrm{DR}{ }^{+}$acquired a phenotype similar in frequency to the one observed in mature peripheral blood $\mathrm{CD} 8^{+} \mathrm{HLA}_{-} \mathrm{DR}^{+}$ Treg, including sharply decreased frequency of CD127 $(p=$ $0.0002)$, increased frequency of PD-1 $(p=0.01)$, TIGIT $(p$ $=0.0084)$, and CTLA-4 $(p=0.02)$, and preservation of the naive phenotype. The ability of $\mathrm{CB} C D 8^{+} \mathrm{HLA}-\mathrm{DR}^{+}$to rapidly acquire these regulatory molecules may explain the suppressor capacity of ex vivo $\mathrm{CB} \mathrm{CD}^{+} \mathrm{HLA}^{-\mathrm{DR}^{+}}$we previously reported (5).

We also analyzed the developmental stage of $\mathrm{CD}^{+} \mathrm{HLA}-$ $\mathrm{DR}^{-}$and $\mathrm{CD}^{+}{ }^{+} \mathrm{HLA}-\mathrm{DR}^{+}$cells in peripheral blood (PB) and cord blood (CB) mononuclear cells. Meanwhile PB $\mathrm{CD}^{+} \mathrm{HLA}^{-\mathrm{DR}^{-}}$cells showed a higher frequency of naïve cells $\left(\mathrm{CD} 45 \mathrm{RA}^{+} \mathrm{CCR}^{+}{ }^{+} \mathrm{CD} 27^{+} \mathrm{CD} 28^{+}\right)(p<0.0001)$, most $\mathrm{CD}^{+}{ }^{+} \mathrm{HLA}_{-} \mathrm{DR}^{+}$Treg have an increased number of late differentiated cells $\left(\mathrm{CD}_{4} \mathrm{RA}^{+} \mathrm{CCR}^{-} \mathrm{CD} 27^{-} \mathrm{CD} 28^{-}\right)(p=$ 0.0317), memory $\left(\mathrm{CD} 45 \mathrm{RA}^{-} \mathrm{CCR} 7^{+/-} \mathrm{CD} 27^{+} \mathrm{CD} 28^{+}\right)(p<$ $0.0001)$, and effector $\left(\mathrm{CD} 45 \mathrm{RA}^{-} \mathrm{CCR} 7^{-} \mathrm{CD} 27^{-} \mathrm{CD} 28^{-}\right)(p=$ 0.0003 ) (Figures $\mathbf{3 A}, \mathbf{B}$ ). Conversely, as expected, the frequency of late differentiated, memory and effector $\mathrm{T}$ cells within cord blood were almost undetectable, being mostly $\mathrm{CD} 8^{+} \mathrm{HLA}^{-\mathrm{DR}^{-}}$ and $\mathrm{CD}^{+}{ }^{+} \mathrm{HLA}-\mathrm{DR}^{+}$naïve cells (Figures $\mathbf{3 A}, \mathbf{B}$ ). 
A

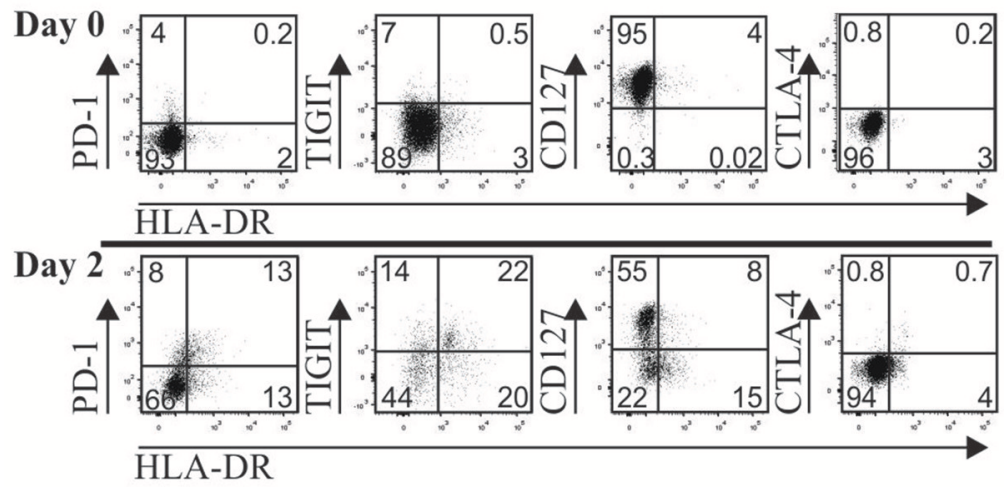

C

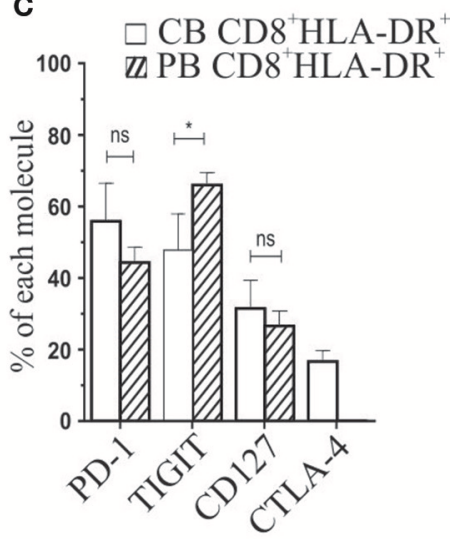

B

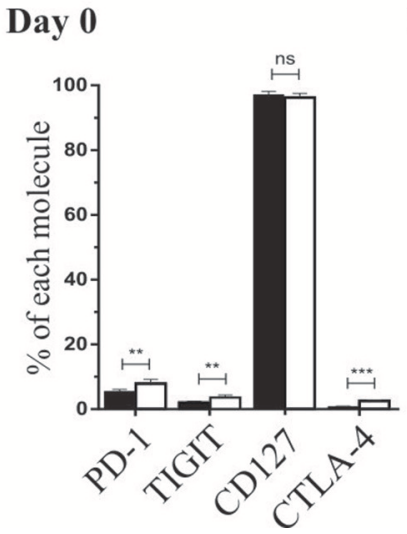

Day 2 CB CD8 ${ }^{+} \mathrm{HLA}^{-D R}{ }^{-}$
$\square \mathrm{CB}$ CD 8 HLA-DR

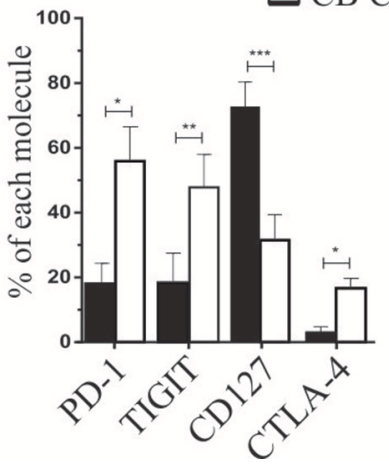

FIGURE 2 | After TCR activation, cord blood CD8 ${ }^{+} \mathrm{HLA}^{-D R^{+}}$Treg cells acquire a peripheral blood-like phenotype. (A) Representative dot plots show PD-1, TIGIT, CD127 and CTLA-4 expression after CB mononuclear cells activation for 2 days with plate-coated aCD3 $(1 \mu \mathrm{g} / \mathrm{mL})$ and soluble aCD28 ( $1 \mu \mathrm{g} / \mathrm{mL})$. Analysis was performed on gated CD8 ${ }^{+}$cells at day 0 (Upper) and day 2 after activation (Lower). (B) Comparative frequency of PD-1, TIGIT, CD127 and CTLA-4 gated on $\mathrm{CD}^{+}{ }^{+} \mathrm{HLA}-\mathrm{DR}{ }^{-}$and $\mathrm{CD} 8^{+} \mathrm{HLA}-\mathrm{DR}^{+}$subsets, and presented as mean frequency $\pm \mathrm{SEM}$ from six independent experiments. (C) Comparative frequency of CB and PB PD-1, TIGIT, CD127 and CTLA-4 on day 2 after activation (gated on each CD8 subset). Paired or unpaired $t$-test. ${ }^{*} p<0.05 ;{ }^{* *} p<0.01 ;{ }^{* \star *} p<0.001$.

\section{Immunosuppressive Properties of CD8 $^{+}$HLA-DR $^{+}$Treg Cells Are Associated With PD-1 Molecule}

Previously we reported the involvement of CTLA-4 in the suppressor mechanism of these cells (5). Given the high frequency and expression of $\mathrm{PD}-1$ on $\mathrm{CD} 8^{+} \mathrm{HLA}^{-\mathrm{DR}^{+}}$Treg, we investigated the effect of an anti-PD-1 neutralizing antibody on the suppressor activity of this subset. We assessed the in vitro suppressive capacity of purified $\mathrm{CD}^{+} \mathrm{HLA}^{-\mathrm{DR}}{ }^{-}$and $\mathrm{CD}^{+}{ }^{+} \mathrm{HLA}_{-\mathrm{DR}}{ }^{+} \mathrm{T}$ cells by diluting CellTrace Violet-labeled autologous PBMCs (hereafter called responder cells) co-cultured with each $\mathrm{CD}^{+} \mathrm{T}$ cell subset, and stimulated for 4 days with anti-CD3 plus anti-CD28 antibodies. Purified CD8 ${ }^{+}$HLA-DR $^{+}$ Treg were able to suppress the proliferative response of activated responder cells (Figure 4A). Anti-PD-1 antibody at $1 \mu \mathrm{g} / \mathrm{mL}$ fully abrogates the suppressor effect of $\mathrm{CD}^{+}{ }^{+} \mathrm{HLA}-\mathrm{DR}{ }^{+}$Treg cells $(p=0.0015)$ (Figure 4B; Table 1). Similarly, an anti-PDL1 neutralizing antibody induces the same effect (Figure S2). To further analyze the potential target population, we investigated the effect of adding $\mathrm{CD} 8^{+} \mathrm{HLA}-\mathrm{DR}^{+}$to gated $\mathrm{CD} 4^{+}$or $\mathrm{CD}^{+}$
CellTrace Violet-labeled responder cells. Addition of CD8 ${ }^{+} \mathrm{HLA}-$ $\mathrm{DR}^{+}$induced a decrease of over $50 \%$ in the proliferative capacity of $\mathrm{CD}^{+}$responder $\mathrm{T}$ cells and a relatively lower proliferative capacity of responder $\mathrm{CD}^{+}$cells. Strikingly, anti-PD- 1 antibody only abrogates the suppressor effect induced on $\mathrm{CD}^{+}$responder cells $(p=0.0192)$ (Figure 4C; Table 2). To elucidate if the different suppressor behavior over $\mathrm{CD}^{+}$and $\mathrm{CD}^{+}$responder cells was associated to their PD-1 and PD-L1 expression, we analyzed the kinetics of these molecules on days 0 and 4 during the suppression culture. We observed that after activation PD-1 and PD-L1 increased in a similar way on both $\mathrm{CD}^{+}$ and $\mathrm{CD}^{+}$responder cells (Figure S3). As also depicted in the same figure, CTLA- 4 behaved similarly to PD-1 and PDL1 on both responder subsets. These results suggest that the different effect observed on $\mathrm{CD}^{+}$and $\mathrm{CD}^{+}{ }^{+}$responder cells is independent of their PD-1 or PD-L1 expression. However, when anti-CTLA-4 was added together with anti-PD-1, the suppressor effect on $\mathrm{CD}^{+}{ }^{+}$responder cells was also abrogated (Figure S4). All together, these results suggest that $\mathrm{CD} 8^{+} \mathrm{HLA}^{-D R^{+}}$Treg suppress both $\mathrm{CD}^{+}{ }^{+}$and $\mathrm{CD} 8^{+}$responder populations, but only 

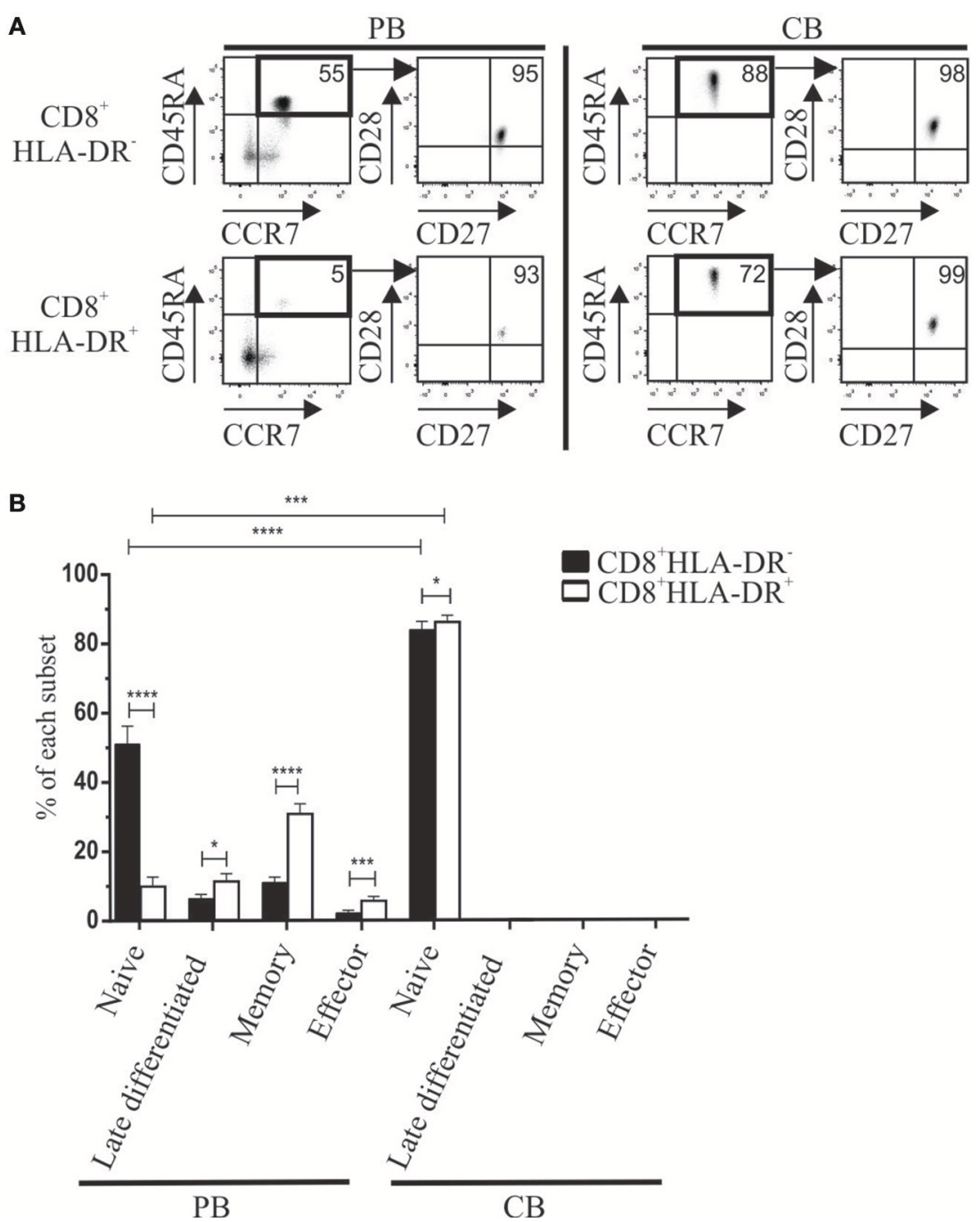

FIGURE 3 | Differences in maturation status detected in $\mathrm{CD}^{+} \mathrm{HLA}^{-D R^{-}}$and CD8 ${ }^{+} \mathrm{HLA}-\mathrm{DR}{ }^{+}$Treg cells from adult peripheral blood (PB) or cord blood (CB). (A) Representative dot plots show the expression of CD45RA vs. CCR7, and CD28 vs. CD27 used herein to define the maturation stage of peripheral blood ( $n=13$ ) (Left) and cord blood mononuclear cells $(n=6)$ (Right). Arrows indicate the sequence of the analysis. (B) Shows comparative frequency of each maturation stage between $\mathrm{CD}^{+} \mathrm{HLA}^{-D R^{-}}$and CD8 ${ }^{+} \mathrm{HLA}-\mathrm{DR}^{+}$in PB $(n=13)$ and $\mathrm{CB}(n=6)$. Data is presented as mean frequency $\pm \mathrm{SEM}$. Paired and unpaired $t$-test were used when comparing results from the same donor or comparing PB and CB samples, respectively. ${ }^{\star} p<0.05 ;{ }^{\star \star \star} p<0.001 ;{ }^{\star \star \star \star} p<0.0001$.

$\mathrm{CD}^{+}$proliferation is downregulated through $\mathrm{PD}-1$ molecule expressed on $\mathrm{CD}^{+}{ }^{+} \mathrm{HLA}-\mathrm{DR}^{+}$Treg. However, the combined addition of both anti-PD-1 and anti-CTLA- 4 were able to suppress also $\mathrm{CD}^{+}$responder cells. Of note, the addition of sorted $\mathrm{CD}^{+} \mathrm{HLA}^{-} \mathrm{DR}^{+}$(but not $\mathrm{CD} 8^{+} \mathrm{HLA}^{-\mathrm{DR}^{-}}$) induced 37 $\pm 6.5 \%$ of $7 \mathrm{AAD}^{+}$cells within responder $\mathrm{CD}^{+}$cells $(p=$ 0.0327 ), with no significant effect on $\mathrm{CD}^{+}$cells. This effect was not reversed by the addition of the anti-PD-1 antibody (Figure 4D).

When PBMCs were stimulated for 4 days with antiCD3 plus anti-CD28, and proliferation measured by $\mathrm{Ki}$ 67 expression, we observed that $\mathrm{CD}^{+} \mathrm{HLA}^{-\mathrm{DR}^{+}}$Treg cells showed a much stronger proliferative response (Figure 5A). Within these $\mathrm{Ki}-67^{+}$proliferative cells, we detected the co-expression of PD-1 (Figure 5B). This co-expression was observed in $40 \pm 15 \%$ of $\mathrm{CD}^{+} \mathrm{HLA}^{+} \mathrm{DR}^{+}$Treg. During the suppressor assay we also utilized 7-AAD to discriminate between dead and viable cells within the CellTrace Violetnegative sorted $\mathrm{CD}^{+}{ }^{+} \mathrm{HLA}-\mathrm{DR}^{-}$or $\mathrm{CD} 8^{+} \mathrm{HLA}-\mathrm{DR}{ }^{+}$. Increased frequency of non-viable cells was detected in sorted CD8 ${ }^{+} \mathrm{HLA}-$ $\mathrm{DR}^{+}$cells: 40 vs. $5 \%$ in $\mathrm{CD}^{+} \mathrm{HLA}^{-\mathrm{DR}^{-}}$(irrespective of the ratio of responder and sorted CD8 cells; Figure 5C). These results suggest that $\mathrm{CD}^{+} \mathrm{HLA}-\mathrm{DR}^{+}$Treg have an elevated renewal rate (high proliferation rate and high death rate).

\section{Expression of HLA-DR on Highly Purified CD8 $^{+}$HLA-DR $^{-}$And CD8 ${ }^{+}$HLA-DR $^{+}$Cells}

To assess the stability of $\mathrm{CD}^{+} \mathrm{HLA}^{-\mathrm{DR}^{+}}$Treg cells, $\mathrm{CD} 8^{+}$ depleted PBMCs were co-cultured with highly purified 
A

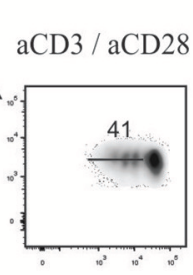

No stimulation
$+\mathrm{CD}^{+}$

HLA-DR $^{+} 1: 1$

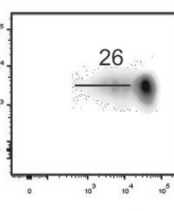

$+\mathrm{CD}^{+}$

HLA-DR 1:1
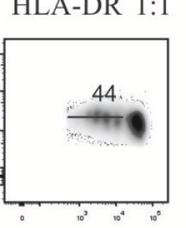

CellTrace Violet

C

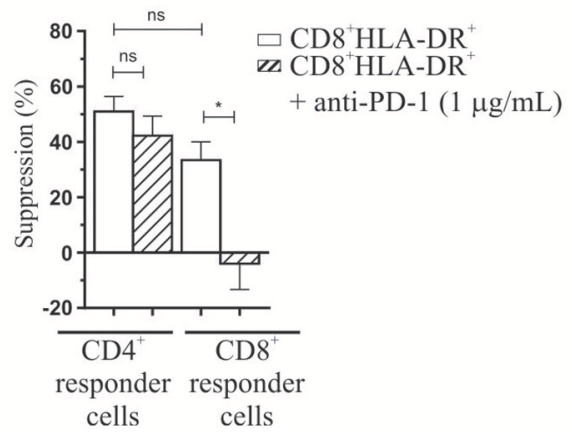

$+\mathrm{CD}^{+}$

HLA-DR $^{+} 1: 1$

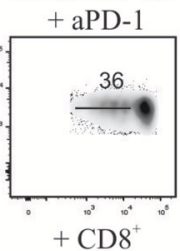

HLA-DR 1:1

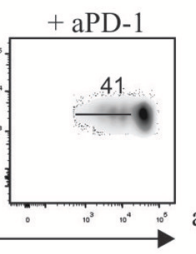

B

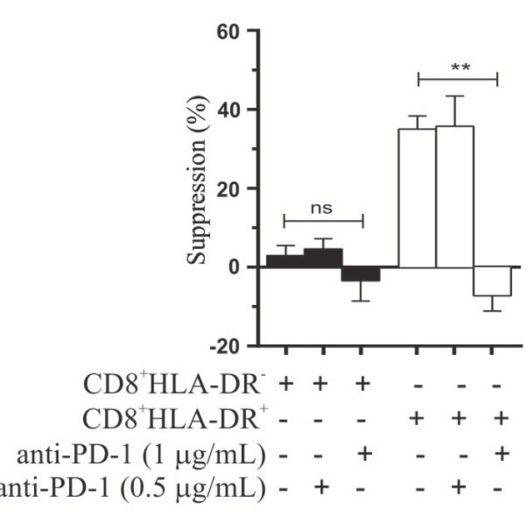

D

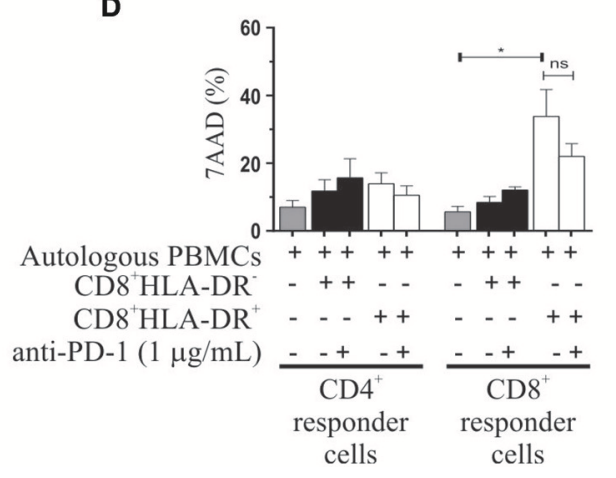

FIGURE 4 | Immunosuppressive properties of $\mathrm{CD}^{+} \mathrm{HLA}-\mathrm{DR}{ }^{+}$Treg. Autologous PBMC labeled with CellTrace Violet were used as responder cells. CD8 ${ }^{+} \mathrm{HLA}-\mathrm{DR}{ }^{-}$ and $\mathrm{CD}^{+}{ }^{+} \mathrm{HLA}-\mathrm{DR}^{+}$sorted cells were cultured with $5 \times 10^{4} \mathrm{PBMC}$ in a 1:1 ratio (suppressor: responder). After 4 days' activation with aCD3/aCD28 $(1 \mu \mathrm{g} / \mathrm{mL})$ proliferation was measured by CellTrace Violet dilution. (A) Representative dot plots from gated $\mathrm{CD}^{+}{ }^{+}$cells showing the role of anti-PD- 1 in reversing suppressor capacity of $\mathrm{CD} 8^{+} \mathrm{HLA}^{-D R^{+}}$Treg cells. (B) Shows mean frequency of suppression induced by $\mathrm{CD} 8^{+} \mathrm{HLA}-\mathrm{DR}^{+}$Treg and the reversion effect after addition of anti-PD-1 antibody $(n=5)$. (C) Similar to the analysis performed in (B) but analyzed on gated CD4 ${ }^{+}$or $C D 8^{+}$T cells $(n=4)$. (D) Shows mean frequency of 7AAD positive cells at day 4 of the suppression assay $(n=5)$. Data is presented as mean \pm SEM. Paired $t$-test. ${ }^{*} p<0.05 ;{ }^{* *} p<0.01$.

TABLE 1 | CD8 ${ }^{+}$HLA-DR ${ }^{+}$Treg mechanism of action.

\begin{tabular}{|c|c|}
\hline & $\begin{array}{c}\text { Suppression } \\
\text { (Average } \pm \text { SEM) }\end{array}$ \\
\hline $\mathrm{CD}^{+} \mathrm{HLA}^{-\mathrm{DR}^{-}}(1: 1)$ & $2.9 \pm 2.5$ \\
\hline $\begin{array}{l}\mathrm{CD}^{+}{ }^{+H L A-D R^{-}}(1: 1) \\
+ \text { aPD-1 }(1 \mu \mathrm{g} / \mathrm{mL})\end{array}$ & $-3.4 \pm 5.1$ \\
\hline $\mathrm{CD}^{+} \mathrm{HLA}^{-\mathrm{DR}^{+}}(1: 1)$ & $35 \pm 3.4$ \\
\hline $\begin{array}{l}\text { CD8 }^{+} \mathrm{HLA}^{-D R^{+}}(1: 1) \\
+\mathrm{aPD}-1(1 \mu \mathrm{g} / \mathrm{mL})\end{array}$ & $-7 \pm 3.8$ \\
\hline
\end{tabular}

$\mathrm{CD}^{+}{ }^{+} \mathrm{HLA}-\mathrm{DR}{ }^{-}$or $\mathrm{CD}^{+} \mathrm{HLA}^{-\mathrm{DR}^{+}}$cells. Additionally, HLA-DR and Ki-67 expression were evaluated after 4 days activation with anti-CD3 plus anti-CD28. Meanwhile 34\% of $\mathrm{CD}{ }^{+} \mathrm{HLA}^{-\mathrm{DR}^{-}}$cells acquire the HLA-DR molecule, almost all $\mathrm{CD}^{+}{ }^{+} \mathrm{HLA}-\mathrm{DR}^{+}$Treg cells remain $\mathrm{HLA}^{+} \mathrm{DR}^{+}$(87\%). Notably, when $\mathrm{CD}^{+} \mathrm{HLA}^{-\mathrm{DR}^{-}}$subset were co-cultured with the $\mathrm{CD}^{+}$-depleted PBMCs $41 \%$ acquired Ki-67, that contrasted with the acquisition of $\mathrm{Ki}-67$ by $80 \%$ of the $\mathrm{CD}^{+}{ }^{+} \mathrm{HLA}_{-\mathrm{DR}}{ }^{+}$cells (Figure 6). These results suggest that a
TABLE 2 | Suppression effect of CD8 ${ }^{+} H L A-D R^{+}$Treg cells on $\mathrm{CD} 4^{+}$and $\mathrm{CD} 8^{+}$ target cells.

\begin{tabular}{|c|c|c|}
\hline & $\begin{array}{c}\text { Suppression } \\
\text { (Average } \pm \text { SEM) } \\
\text { on target CD4 }{ }^{+} \mathrm{T} \text { cells }\end{array}$ & $\begin{array}{c}\text { Suppression } \\
\text { (Average } \pm \text { SEM) } \\
\text { on target } \mathrm{CDB}^{+} \mathrm{T} \text { cells }\end{array}$ \\
\hline $\mathrm{CD}^{+} \mathrm{HLA}^{-\mathrm{DR}^{+}}(1: 1)$ & $51 \pm 5.3$ & $33.4 \pm 6.5$ \\
\hline $\begin{array}{l}\text { CD8 }^{+} \mathrm{HLA}^{-} \mathrm{DR}^{+}(1: 1) \\
+\mathrm{aPD}-1(1 \mu \mathrm{g} / \mathrm{mL})\end{array}$ & $42 \pm 7$ & $-4 \pm 9.2$ \\
\hline
\end{tabular}

subpopulation of $\mathrm{CD}^{+} \mathrm{HLA}^{-\mathrm{DR}^{+}}$Treg cells can be induced from $\mathrm{CD}^{+}{ }^{+} \mathrm{HLA}-\mathrm{DR}^{-}$after TCR activation.

\section{CD8 $^{+}$HLA-DR $^{+}$Treg Cells Are Not Exhausted T Cells}

The expression of PD-1, TIGIT and TIM-3 has been associated with exhausted cells $(17,18)$. As described in the previous section, $\mathrm{CD}^{+}{ }^{+} \mathrm{HLA}-\mathrm{DR}^{+}$Treg have an elevated renewal rate. Analysis of $\mathrm{CD}^{+} \mathrm{HLA}^{-\mathrm{DR}^{+}}$Treg within PMA/Ionomycin stimulated PBMCs showed that they had an increased number of cells 
A
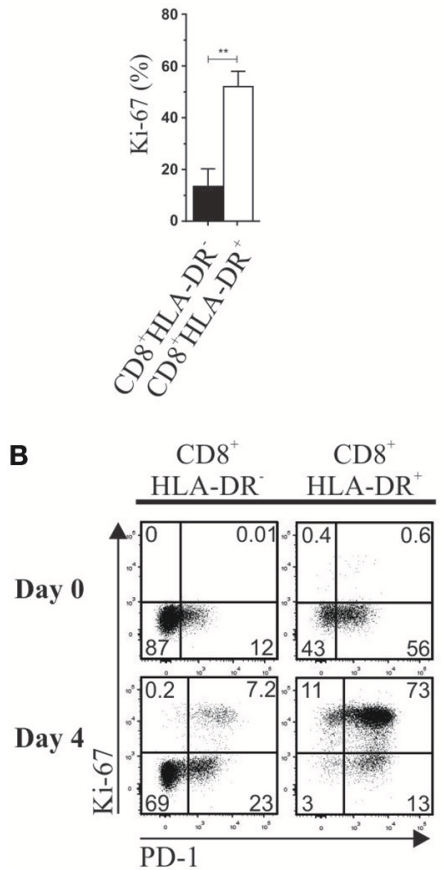

$\mathrm{CD}^{+}$
PD-1
C

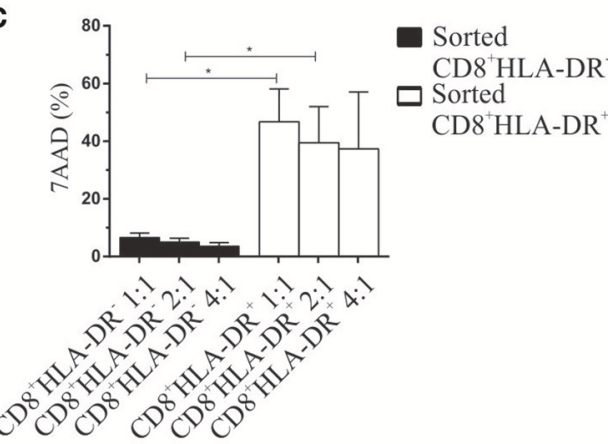

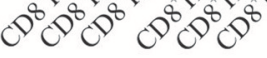

FIGURE 5 | CD8 ${ }^{+}$HLA-DR ${ }^{+}$Treg have a high renewal rate. PBMC from healthy donors isolated by density gradient were activated with plate-coated aCD3 ( $\left.1 \mu \mathrm{g} / \mathrm{mL}\right)$ and soluble aCD28 $(1 \mu \mathrm{g} / \mathrm{mL})$. Surface PD-1 and intracellular Ki-67 were stained on day 0 and 4 after activation. Ten minutes before reading the tubes in the flow cytometer, 7AAD death marker was added to the samples. (A) Mean frequency of Ki-67 on CD8 ${ }^{+} \mathrm{HLA}^{-D R^{-}}$and CD8 ${ }^{+} \mathrm{HLA}^{-D R^{+}}$cells after activation $(n=7)$. (B) Representative dot plots show the co-expression of PD-1 and Ki-67 gated on CD8 ${ }^{+} \mathrm{HLA}_{-} \mathrm{DR}^{-}$and $\mathrm{CD}^{+} \mathrm{HLA}^{-\mathrm{DR}}{ }^{+}$subsets $(n=7)$. (C) Shows mean frequency of 7AAD 4 days after activation on sorted $\mathrm{CD} 8^{+} \mathrm{HLA}-\mathrm{DR}{ }^{-}$and $\mathrm{CD} 8^{+} \mathrm{HLA}-\mathrm{DR}{ }^{+}$cells, cultured with autologous PBMC $(n=5)$. Paired or unpaired $t$-test. ${ }^{*} p<0.05$; ${ }^{* \star} p<0.01$.

expressing IFN $-\gamma(p=0.0098), \operatorname{TNF} \alpha(p=0.0004)$, and CD107a $(p=0.0006)$. Moreover, no differences in secretion levels of granzyme B were detected when $\mathrm{CD} 8^{+} \mathrm{HLA}-\mathrm{DR}^{-}$and $\mathrm{CD}^{+}{ }^{+} \mathrm{HLA}-\mathrm{DR}^{+}$subsets were compared (Figures 7A,B). Apart from their capacity to secrete cytokines and degranulate, these cells lack expression of the terminally exhausted marker TIM-3 (Figure 1A).

Given that PD-1 ligation can antagonize CD3 signaling, we evaluated the capacity of these Treg to secrete IFN- $\gamma$ and degranulate in response to anti-CD3 plus antiCD28 stimulation. Similarly to PMA/Ionomycin stimuli, a higher frequency of CD107a $(p=0.0178)$ and IFN- $\gamma$ $(p=0.095)$ cells was observed in $\mathrm{CD}^{+} \mathrm{HLA}^{-\mathrm{DR}^{+}}$cells than in $\mathrm{CD}^{+} \mathrm{HLA}_{-\mathrm{DR}}^{-}$(Figure S5), suggesting that $\mathrm{CD}^{+}{ }^{+} \mathrm{HLA}_{-} \mathrm{DR}^{+}$Treg are capable of responding to TCR ligation.

In basal conditions, total $\mathrm{CD}^{+} \mathrm{T}$ cells lack expression of PD-1 ligand 1 (PD-L1) and TIGIT ligand CD155. To mimic suppression assay conditions, PBMCs were activated with antiCD3 plus anti-CD28, and PD-L1 and CD155 expression was evaluated on day 4 after activation. A higher frequency of both receptors $(p=0.0007$ and $p=0.0008$, respectively) was detected in activated $\mathrm{CD}^{+}{ }^{+} \mathrm{HLA}-\mathrm{DR}{ }^{+}$Treg cells than in their $\mathrm{CD} 8^{+} \mathrm{HLA}-$ $\mathrm{DR}^{-}$counterpart (Figures $\mathbf{8 A}, \mathbf{B}$ ).

\section{DISCUSSION}

In our previous work (5) we showed that human $\mathrm{CD} 8^{+} \mathrm{HLA}$ $\mathrm{DR}^{+}$but not $\mathrm{CD}^{+} \mathrm{HLA}^{-\mathrm{DR}^{-}}$cells suppress proliferation of autologous PBMCs responder cells through CTLA-4 coinhibitory molecule. Our present data further characterize this regulatory subset by identifying a wide array of molecules showing preferential expression within $\mathrm{CD} 8^{+} \mathrm{HLA}-\mathrm{DR}^{+}$Treg over $\mathrm{CD}^{+} \mathrm{HLA}^{-\mathrm{DR}}{ }^{-}$cells. The complete phenotype includes, in addition to CTLA-4, expression of checkpoint receptors PD-1 and TIGIT and increased frequency of CCR4 and CCR5 chemokine receptors. Strikingly, this phenotype profile shared most of the molecules expressed by a subpopulation of $\mathrm{CD}^{+}{ }^{+} \mathrm{FOXP} 3^{+}$Treg cells with stronger regulatory capacity than conventional $\mathrm{CD}^{+} \mathrm{FOXP}^{+}$Treg $(11,19)$. Low expression of CD127 and memory and effector-like phenotype are other features also shared by $\mathrm{CD} 8^{+} \mathrm{HLA}_{-} \mathrm{DR}^{+}$and $\mathrm{CD}^{+}{ }^{+} \mathrm{FOXP} 3^{+}$ Treg cells (20).

Umbilical cord blood (CB) is a source of immature lymphocytes. $\mathrm{CB} C D 8^{+} \mathrm{T}$ cells are predominantly naïve cells defined by their $\mathrm{CD} 45 \mathrm{RA}^{+} \mathrm{CCR} 7{ }^{+} \mathrm{CD} 27^{+} \mathrm{CD} 28^{+}$co-expression. Concordantly with the similar naive stage, both subsets showed low or absent frequency of CTLA-4, TIGIT and PD-1 molecules and high frequency of IL-7 receptor CD127. However, after only 


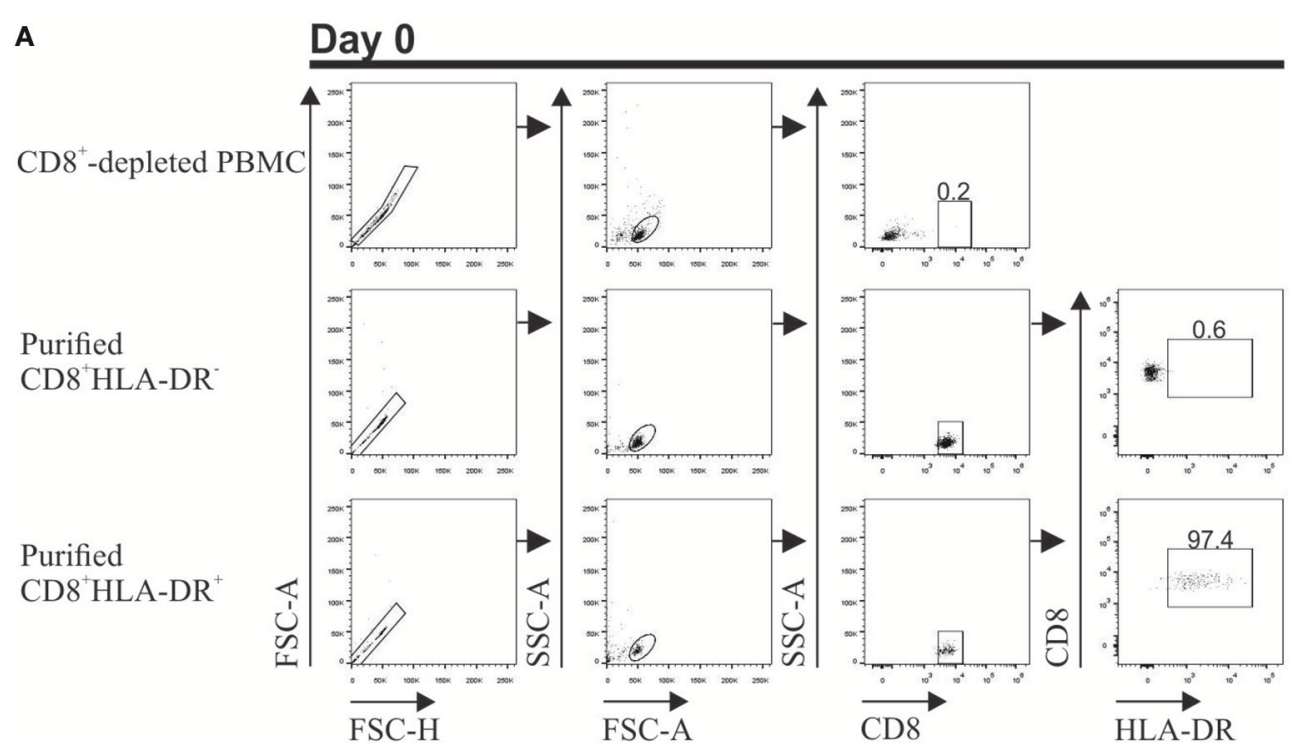

B

Day 4 after activation

CD $8^{+}$-depleted PBMC $+\mathrm{aCD} 3 / \mathrm{aCD} 28$

$\mathrm{CD}^{+}$-depleted PBMC $+\mathrm{CD} 8^{+}$HLA-DR

$+\mathrm{aCD} 3 / \mathrm{aCD} 28$

$\mathrm{CD}^{+}$-depleted PBMC

+ CD 8 HLA-DR

$+\mathrm{aCD} 3 / \mathrm{aCD} 28$
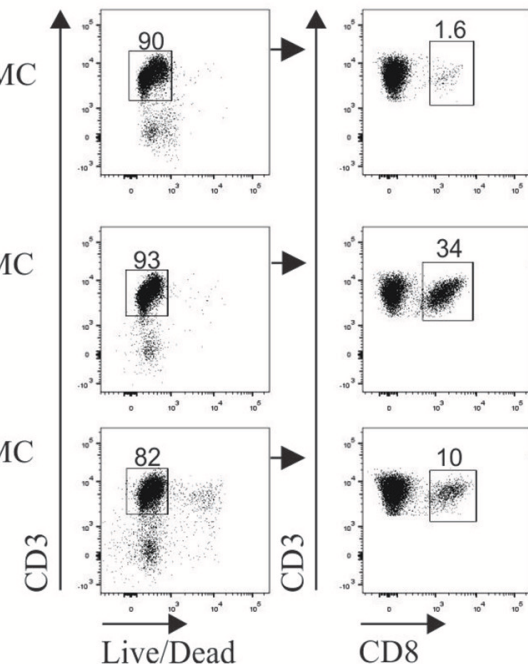

FIGURE 6 | Stable expression of HLA-DR on in vitro activated CD8 ${ }^{+} \mathrm{HLA}-\mathrm{DR}^{+}$Treg cells. PBMCs from healthy individuals were isolated, stained, and the following populations were purified in a FACS Aria II cell sorter: CD8 ${ }^{+}$-depleted mononuclear cells, CD8 ${ }^{+} \mathrm{HLA}_{-} \mathrm{DR}^{-}$and $\mathrm{CD}^{+} \mathrm{HLA}^{-\mathrm{DR}}{ }^{+}$subsets. (A) Dot plots show the purity of each population after sorting. (B) $5 \times 10^{5} \mathrm{CD}^{+}$-depleted PBMCs were culture alone, or co-culture with purified $0.9 \times 10^{5} \mathrm{CD}^{+} \mathrm{HLA}^{-\mathrm{DR}}{ }^{-}$or $0.1 \times 10^{5}$ $\mathrm{CD}^{+}{ }^{+} \mathrm{HLA}_{-\mathrm{DR}}{ }^{+}$cells. On day 4 after aCD3 $(1 \mu \mathrm{g} / \mathrm{mL}) / \mathrm{aCD} 28(1 \mu \mathrm{g} / \mathrm{mL})$ activation, surface HLA-DR and intra-cellular Ki-67 were stained. Singlets were excluded and living cells were selected by gating Live/Dead Aqua Fixable death marker-negative cells. HLA-DR and Ki-67 molecules were analyzed within gated CD8+ T cells.

2 days of TCR stimulation, cord blood $\mathrm{CD}^{+} \mathrm{HLA}^{-\mathrm{DR}}{ }^{+}$cells rapidly acquired a phenotype quite similar to peripheral blood $\mathrm{CD} 8{ }^{+} \mathrm{HLA}^{-\mathrm{DR}}{ }^{+}$Treg cells.

The role of CTLA-4 as a mediator of suppressor function within classical CD4 ${ }^{+} \mathrm{FOXP}^{+}{ }^{+}$Treg cells is well known, as well as its capacity to negatively regulate immune responses (21). CTLA4 is constitutively expressed in $\mathrm{CD}^{+}{ }^{+} \mathrm{FOXP} 3^{+}$Treg, probably because this molecule is a target of FOXP3 transcriptional factor (22). In contrast with the constitutive expression of PD-1 and TIGIT on $\mathrm{CD}^{+}{ }^{+}$HLA-DR ${ }^{+}$Treg cells, CTLA- 4 is induced after T cell activation, preferentially restricted to $\mathrm{CD} 8^{+}$cells expressing HLA-DR. Interestingly, and unlike $\mathrm{PB} C D 8^{+} \mathrm{HLA}-\mathrm{DR}^{+}$Treg, umbilical $\mathrm{CB} \mathrm{CD}^{+} \mathrm{HLA}-\mathrm{DR}^{+}$showed augmented frequency of CTLA-4 in basal conditions, which may be explained by the slightly increased level of FOXP3 detected in CB HLA$\mathrm{DR}^{+}$Treg cells (5). Regarding $\mathrm{PB} \mathrm{CD}^{+}{ }^{+} \mathrm{HLA}_{-} \mathrm{DR}^{+}$Treg, our previous work showed that the regulatory effect is exerted by CTLA-4, and requires cell-cell contact. Therefore, blocking of CTLA-4 abrogated its suppressive effect in a dose-dependent manner (5). 


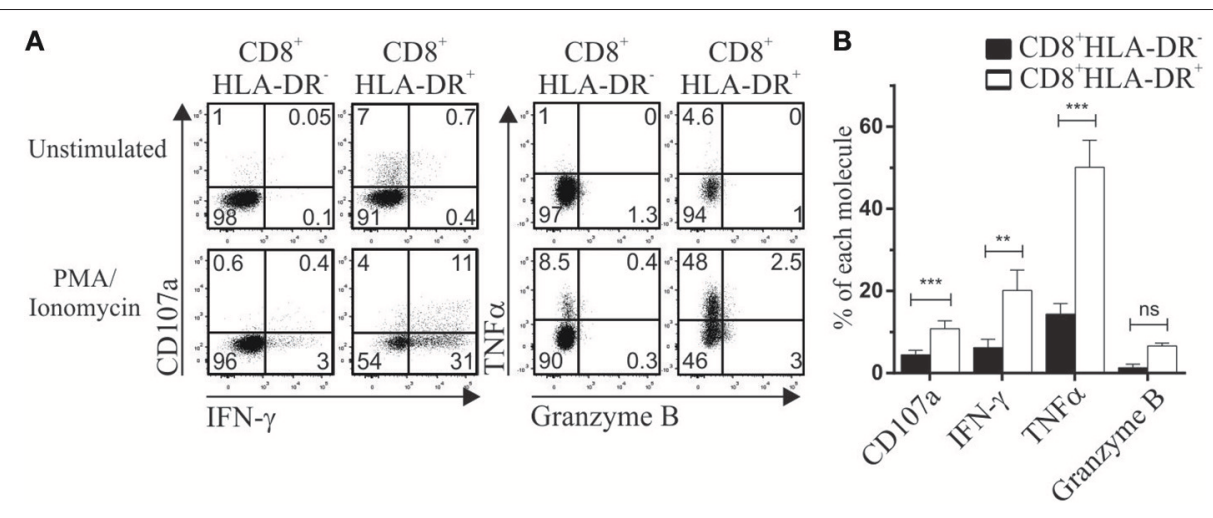

FIGURE 7 | CD8 ${ }^{+} \mathrm{HLA}^{-D R^{+}}$Treg are functionally competent cells. PBMC isolated by density gradient were stimulated for $4 \mathrm{~h}$ with PMA/lonomycin in the presence of monensin. CD107a, IFN- $\gamma$, TNF $\alpha$, and Granzyme B were stained and analyzed by flow cytometry. (A) Dot plots from one representative experiment showing expression of CD107a and IFN- $\gamma$ (Left), TNF $\alpha$ and Granzyme B (Right) within CD8 ${ }^{+}$HLA-DR ${ }^{-}$and CD8 ${ }^{+} \mathrm{HLA}^{-D R^{+}}$cells. (B) Graph shows the comparative frequency of each molecule gated on CD8 ${ }^{+} \mathrm{HLA}-\mathrm{DR}{ }^{-}$and $\mathrm{CD} 8^{+} \mathrm{HLA}-\mathrm{DR}{ }^{+}$subsets $(n=7)$. Data is presented as mean frequency $\pm \mathrm{SEM}$. Paired $t$-test. ${ }^{* *} p<0.01$;

${ }^{* * *} p<0.001$.

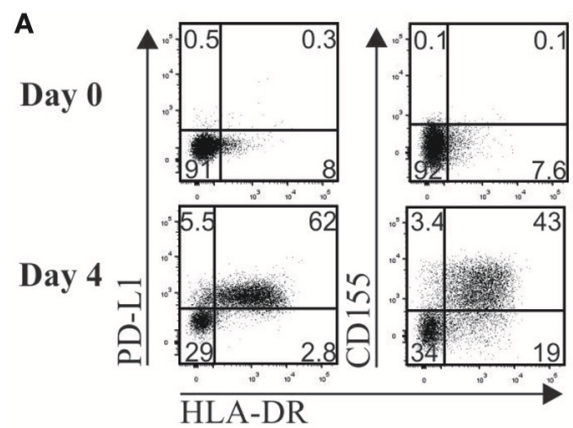

$\mathbf{B}$

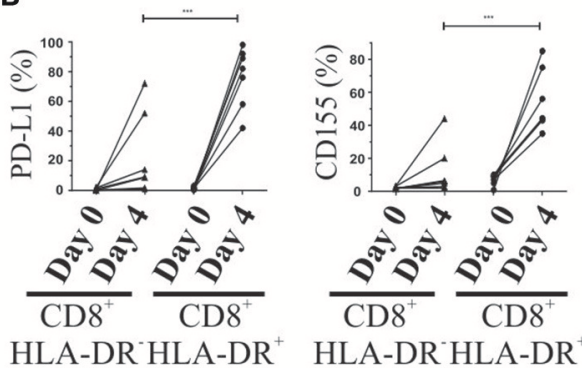

FIGURE 8 | Increased expression of PD-1 and TIGIT ligands (PD-L1 and CD155) after T cell activation. Four days after PBMC activation, PD-L1 and CD155 were stained and analyzed by flow cytometry. (A) Representative dot plots show co-expression of HLA-DR, PD-L1 and CD155 gated on total CD8 ${ }^{+}$ $T$ cells on day 0 (Upper) and day 4 after activation (Lower). (B) Frequency of PD-L1 and CD155 gated on $\mathrm{CD}^{+}{ }^{+} \mathrm{HLA}^{-D R^{-}}$and $\mathrm{CD}^{+}{ }^{+} \mathrm{HLA}-\mathrm{DR}^{+}$subsets detected before and after 4 days' activation. Each point corresponds to an independent experiment $(n=7)$. Paired $t$-test. ${ }^{\star \star \star} p<0.001$.

PD-1 was first identified in 1992 (23). Initially it was believe that PD-1 triggered an inhibitory signal for CD3 signaling (2426). Recent data support that CD28 costimulatory signaling is interrupted after PD-1 engagement rather than $\operatorname{CD} 3(27,28)$, indicating that $\mathrm{PD}-1$ suppresses $\mathrm{T}$ cell function primarily by inactivating CD28 signaling, playing a key role in regulating effector $\mathrm{T}$ cell function and responses to anti-PD-L1/PD-1 therapy. Thus, could be possible that the inactivation of CD28 costimulatory signaling may reproduce the suppressor effect triggered by PD- 1 . PD- 1 expressed in $\mathrm{CD}^{+}{ }^{+} \mathrm{FOXP} 3^{+}$Treg cells plays a central role in regulating peripheral immune responses $(10,12)$. During chronic infection, $\mathrm{CD}^{+}{ }^{+} \mathrm{FOXP} 3^{+}$Treg that upregulate $\mathrm{PD}-1$ showed a stronger suppressor function in mice infected with lymphocytic choriomeningitis virus (12). Within CD ${ }^{+}{ }^{+}$LLA-DR ${ }^{+}$Treg cells, the high frequency of PD-1 strongly suggests that it may be associated with their regulatory capacity. In line with this, we found that an anti-PD-1 neutralizing antibody abrogated their suppressor activity. Multiple evidences seem to support that CTLA-4 and PD-1 receptors inhibit T cell activation by diverse mechanisms (26). Whereas, CTLA-4 increases the threshold needed for $\mathrm{T}$ cell activation by competing with CD28 co-receptor, PD-1 limits immune response at effector $\mathrm{T}$ cell activity level, preferentially in peripheral tissues where PD-L1 is expressed $(8,29,30)$. Consequently, the immune checkpoint blockade by anti CTLA-4 and anti PD-1/PDL1 specific antibodies also differs in its mechanism of action (17).

An open question is whether manipulation of the PD-1/PDL1 pathway is preventing priming or exhaustion, instead of reversing it. In the case of $\mathrm{CD}^{+}{ }^{+} \mathrm{HLA}-\mathrm{DR}^{+}$Treg cells, although similar suppressor activity on $\mathrm{CD}^{+}{ }^{+}$or $\mathrm{CD} 8^{+}$responder cells was detected, we found that PD-1 neutralization specifically abrogates the suppression capacity on $\mathrm{CD}^{+}$responder cells with little effect on $\mathrm{CD}^{+}$responder cells, suggesting that $\mathrm{PD}$ 1 blockade may preferentially affect $\mathrm{CD}^{+} \mathrm{T}$ cells. Moreover, the similar behavior of PD-1, PD-L1, and CTLA- 4 within $\mathrm{CD}^{+}$and $\mathrm{CD}^{+}$responder cells during the co-culture rise the possibility that a third population may be involved in their suppressor mechanisms. For instance, the interaction between $\mathrm{CD} 8^{+} \mathrm{HLA}-$ $\mathrm{DR}^{+}$Treg and APC during the suppression assay should be further addressed, because the lack of reversion of the suppressor effect on $\mathrm{CD}_{4}{ }^{+}$responder cells could be related with the fact that $\mathrm{APC}$ activate naïve $\mathrm{CD}^{+} \mathrm{T}$ cells in the early phase of 
the immune response, typically in lymph nodes, while $\mathrm{CD} 8^{+} \mathrm{T}$ cells activation occurs later presumably improved by $\mathrm{CD} 4^{+} \mathrm{T}$ cells help. This explanation seems to be in line with a previous report of James Allison group (10) showing that anti- CTLA4 , but not anti-PD-1, acts at the initial stage of naïve T-cell activation, affecting $\mathrm{CD}^{+}$effector cells. Similarly, the same group reported that $\mathrm{CD} 4^{+} \mathrm{T}$ cells suffer a preferential expansion in CTLA-4(-/-) mice (31), and behave as key regulator in maintaining $\mathrm{T}$ cell homeostasis of CD4 vs. CD8 T cells (32). Therefore, it was expected that in the present study anti-CTLA-4 in contrast with anti-PD-1 abrogates the suppression on $\mathrm{CD} 4{ }^{+}$ effector cells. To our knowledge, this is the first time that PD1 neutralization was shown to block the suppressor capacity of a $\mathrm{CD}^{+}$Treg population, acting specifically on $\mathrm{CD}^{+}$effector cells.

An additional feature of $\mathrm{CD} 8^{+} \mathrm{HLA}^{-\mathrm{DR}^{+}}$Treg cells is their high proliferative capacity associated with increased frequency of non-viable cells, meaning that they belong to a subset with a high renewal rate. In concordance with a previous study (33), we also found that highly proliferative $\mathrm{CD}^{+} \mathrm{HLA}^{-\mathrm{DR}^{+}}$ showed a high frequency of $\mathrm{PD}-1^{+}$cells. In addition, it was previously reported that $\mathrm{CD} 4{ }^{+} \mathrm{CD} 45 \mathrm{RO}^{+} \mathrm{FOXP} 3^{+} \mathrm{CD} 25^{\text {hi }}$ $\mathrm{T}$ lymphocytes were highly proliferative, compared with memory $\mathrm{CD} 4{ }^{+} \mathrm{CD} 45 \mathrm{RO}^{+} \mathrm{FOXP}^{-} \mathrm{CD} 25^{-}$or naive $\mathrm{CD}^{+}{ }^{+} \mathrm{CD} 45 \mathrm{RA}^{+} \mathrm{FOXP}^{-}{ }^{-} \mathrm{CD} 25^{-}$populations (34). Similarly, in inflamed skin $\mathrm{CD}^{+}$Treg were highly proliferative in comparison with conventional memory $\mathrm{T}$ helper cells (35). Of note, peripheral blood $\mathrm{CD}^{+} \mathrm{HLA}^{-\mathrm{DR}^{+}}$Treg with high proliferative rate also possess a memory-like phenotype. Regarding induced $\mathrm{CD}^{+} \mathrm{HLA}-\mathrm{DR}^{+}$Treg cells, we also showed that a subset of highly purified $\mathrm{CD}^{+} \mathrm{HLA}^{-} \mathrm{DR}^{-}$ $\mathrm{T}$ cells can acquire the expression of HLA-DR. This is in line with our previous report $(5,36)$, where we showed that induced $\mathrm{CD}^{+} \mathrm{HLA}^{-\mathrm{DR}^{+}}$Treg cells sorted after PBMCs activation behave as potent suppressor cells. The addition of highly purified $\mathrm{CD}^{+} \mathrm{HLA}^{-\mathrm{DR}^{+}}$cells to responder PBMCs not only induced suppression of proliferative $\mathrm{CD}^{+}$cells but also induced preferential death of responder $\mathrm{CD}^{+}$ cells without any significant effect on $\mathrm{CD} 4^{+} \mathrm{T}$ cells. This effect was only slightly reversed after PD-1 neutralization, indicating that other mechanism/s may be involved in apoptosis induction. After activation, most $\mathrm{CD}^{+} \mathrm{HLA}_{-} \mathrm{DR}^{+}$Treg express PD-L1. In addition to PD-1, PD-L1 can bind to $\mathrm{CD} 80$ on activated $\mathrm{CD}^{+}$cells, triggering an apoptosis signal (37).

There is an emerging concept that not all FOXP3 ${ }^{+}$Treg are identical and may include distinct phenotypes specialized to selectively regulate specific effector $\mathrm{T}$ cell responses and control inflammation at defined anatomical tissue sites (38). For instance, TIGIT can inhibit T cell responses by binding the ligand CD155 on dendritic cells (DCs) thereby inhibiting IL-12 while inducing IL-10 production (39), or by directly inhibiting T cell activation and proliferation (40-42). Similarly to $\mathrm{CD}^{+} \mathrm{HLA}^{+} \mathrm{DR}^{+}$Treg cells, $\mathrm{CD}^{+}{ }^{\mathrm{FOXP}} 3^{+}$cells with high suppressor function were also associated with TIGIT expression (43), CTLA-4, and PD1 co-inhibitory molecules $(39,40)$, and within CD4 ${ }^{+}$TILs almost exclusively detected on FOXP3 ${ }^{+}$Treg (11). CD8 ${ }^{+}$HLA$\mathrm{DR}^{+}$Treg also showed expression of CD155 TIGIT ligand. The agonistic effect of the anti-TIGIT antibody we used prevented us from observing abrogation of suppression by this antibody.

The expression of chemokine receptors may identify different human Treg cell subsets $(44,45)$. Another important similarity between $\mathrm{CD}^{+}{ }^{-} \mathrm{FXXP}^{+}$and ${ }^{+} \mathrm{CD}{ }^{+}{ }^{+} \mathrm{HLA}-\mathrm{DR}{ }^{+}$Treg is the expression of CCR4, previously associated with stronger

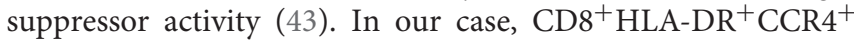
Treg cells showed augmented frequency and expression of PD-1 (data not shown). In line with the elevated expression of CCR4 and PD-1 on Treg cells, it was reported that treatment of T cells with anti-CCR4 immunotherapy enhance not only CD4 but also CD8 immune responses (46).

Exhausted $\mathrm{T}$ cells can be distinguished from $\mathrm{T}$ cell anergy or senescence $(47,48)$. Anergy occurs during $\mathrm{T}$ cell priming by inadequate costimulatory signals whereas senescence is growth arrest after extensive proliferation. In contrast, exhausted $\mathrm{T}$ cells arise from cells which initially gained effector function but were gradually silenced due to continuous TCR stimulation by a persistent antigen (49). High PD-1 expression is a hallmark of "exhausted" $\mathrm{T}$ cells that have experienced high levels of stimulation or reduced $\mathrm{CD}^{+}{ }^{+}$T-cell help (18) as seen during chronic infections and cancer. The principal characteristic of exhausted $\mathrm{T}$ cells is loss of function in a hierarchical manner. IL-2 production and ex vivo killing capacity are lost at the early stage of exhaustion (18). Whereas, TNF $\alpha$ production is lost at an intermediate stage, IFN- $\gamma$ is lost at the advanced stage of exhaustion (50). After a single round of anti-CD3 plus anti-CD28 activation, cord blood $\mathrm{CD}^{+} \mathrm{HLA}^{-\mathrm{DR}}{ }^{+}$cells acquire most of the inhibitory markers associated with exhausted $\mathrm{T}$ cells while retaining their naïve phenotype. Therefore, it was inappropriate to associate this Treg subset with exhausted cells. Also, $\mathrm{CD}^{+}{ }^{+} \mathrm{HLA}-\mathrm{DR}^{+}$lack TIM-3 expression, and after PBMCs stimulation showed increased frequency of IFN- $\gamma$ and $\mathrm{TNF} \alpha$ positive cells and greater degranulation as revealed by CD107a expression. In addition, granzyme B (GzmB), increased in exhausted $\mathrm{T}$ cells (51), showed no differences between $\mathrm{CD}^{+} \mathrm{HLA}^{-\mathrm{DR}^{-}}$and $\mathrm{CD}^{+} \mathrm{HLA}^{-} \mathrm{DR}^{+} \mathrm{T}$ cells. All together, these data strongly argue against $\mathrm{CD} 8^{+} \mathrm{HLA}-\mathrm{DR}^{+}$Treg being exhausted T cells.

Regarding biological implications of $\mathrm{CD} 8^{+} \mathrm{HLA}^{-\mathrm{DR}^{+}}$cells, we observed that these Treg cells were present in TILs of patients with NSCLC at even higher frequencies than $\mathrm{CD} 4{ }^{+} \mathrm{FOXP} 3^{+}$Treg cells (5). These results are supported by a report that TIGIT and PD-1 were expressed by a large percentage of NSCLC-infiltrating $\mathrm{CD}^{+} \mathrm{T}$ cells (52).

Overall, data presented in this study indicates that $\mathrm{CD} 8^{+} \mathrm{HLA}-$ $\mathrm{DR}^{+}$Treg and $\mathrm{CD}^{+}{ }^{+} \mathrm{FOXP} 3^{+}$Treg share phenotypic and functional features, and that they may be similarly involved in the control of antitumor immune responses and autoimmunity. Therefore, therapeutic strategies that aim to overcome Treg activity as a means of enhancing antitumor immune responses should integrate this novel intratumoral subset of highly suppressive $\mathrm{CD} 8^{+} \mathrm{HLA}-\mathrm{DR}{ }^{+}$Treg cells. 


\section{AUTHOR CONTRIBUTIONS}

$\mathrm{AM}$ and LF have made substantial contributions to the conception and design, the acquisition, analysis and interpretation of the data, and wrote the paper. $\mathrm{LF}$ also obtained funding. SB, LB, and PB performed experiments, and help with the analysis and interpretation of data.

\section{FUNDING}

This work was supported by grants from Agencia Nacional de Promoción Científica y Tecnológica (ANPCYT) PICT2014 0925 and Buenos Aires University (UBA) grant 200201330100001.

\section{REFERENCES}

1. Sakaguchi S. Regulatory T cells: history and perspective. Methods Mol Biol. (2011) 707:3-17. doi: 10.1007/978-1-61737-979-6_1

2. Hori S, Nomura T, Sakaguchi S. Control of regulatory T cell development by the transcription factor Foxp3. Science (2003) 299:1057-61. doi: $10.1126 /$ science. 1079490

3. Abbas AK, Benoist C, Bluestone JA, Campbell DJ, Ghosh S, Hori S, et al. Regulatory T cells: recommendations to simplify the nomenclature. Nat Immunol. (2013) 14:307-8. doi: 10.1038/ni.2554

4. Samstein RM, Josefowicz SZ, Arvey A, Treuting PM, Rudensky AY. Extrathymic generation of regulatory $\mathrm{T}$ cells in placental mammals mitigates maternal-fetal conflict. Cell (2012) 150:29-38. doi: 10.1016/j.cell.2012.05.031

5. Arruvito L, Payaslian F, Baz P, Podhorzer A, Billordo A, Pandolfi J, et al. Identification and clinical relevance of naturally occurring human CD8+HLA-DR+ regulatory T cells. J Immunol. (2014) 193:4469-76. doi: 10.4049/jimmunol.1401490

6. Xu Z, Ho S, Chang CC, Zhang QY, Vasilescu ER, Vlad G, Suciu-Foca N. Molecular and Cellular Characterization of Human CD8 T Suppressor Cells. Front Immunol. (2016) 7:549. doi: 10.3389/fimmu.2016.00549

7. Rifa'i M, Kawamoto Y, Nakashima I, Suzuki H. Essential roles of $\mathrm{CD} 8{ }^{+} \mathrm{CD} 122^{+}$regulatory $\mathrm{T}$ cells in the maintenance of $\mathrm{T}$ cell homeostasis. J Exp Med. (2004) 200:1123-34. doi: 10.1084/jem.20040395

8. Fife BT, Bluestone JA. Control of peripheral T-cell tolerance and autoimmunity via the CTLA-4 and PD-1 pathways. Immunol Rev. (2008) 224:166-82. doi: 10.1111/j.1600-065X.2008.00662.x

9. Krummel MF, Allison JP. CD28 and CTLA-4 have opposing effects on the response of $\mathrm{T}$ cells to stimulation. J Exp Med. (1995) 182:459-65. doi: 10.1084 /jem.182.2.459

10. Chikuma S, Terawaki S, Hayashi T, Nabeshima R, Yoshida T, Shibayama S, et al. PD-1-mediated suppression of IL-2 production induces $\mathrm{CD}^{+} \mathrm{T}$ cell anergy in vivo. J Immunol. (2009) 182:6682-9. doi: 10.4049/jimmunol.0900080

11. Kurtulus S, Sakuishi K, Ngiow SF, Joller N, Tan DJ, Teng MW, et al. TIGIT predominantly regulates the immune response via regulatory $\mathrm{T}$ cells. J Clin Invest. (2015) 125:4053-62. doi: 10.1172/JCI81187

12. Park HJ, Park JS, Jeong YH, Son J, Ban YH, Lee BH, et al. PD-1 upregulated on regulatory $\mathrm{T}$ cells during chronic virus infection enhances the suppression of CD8+ $\mathrm{T}$ cell immune response via the interaction with PD-L1 expressed on CD8+ T cells. J Immunol. (2015) 194:5801-11. doi: 10.4049/jimmunol.1401936

13. Oo YH, Weston CJ, Lalor PF, Curbishley SM, Withers DR, Reynolds GM, et al. Distinct roles for CCR4 and CXCR3 in the recruitment and positioning of regulatory $\mathrm{T}$ cells in the inflamed human liver. J Immunol. (2010) 184:2886-98. doi: 10.4049/jimmunol.0901216

14. Wysocki CA, Jiang Q, Panoskaltsis-Mortari A, Taylor PA, McKinnon KP, Su L, et al. Critical role for CCR5 in the function of donor CD4+CD25+ regulatory $\mathrm{T}$ cells during acute graft-versus-host disease. Blood (2005) 106:3300-7. doi: 10.1182/blood-2005-04-1632
ACKNOWLEDGMENTS

We thank the staff of the Cord Blood Bank of the Hospital de Pediatría S.A.M.I.C. Prof. Dr. Juan P. Garrahan for their support in the collection of cord blood samples, and colleagues from our institute for providing blood samples.

\section{SUPPLEMENTARY MATERIAL}

The Supplementary Material for this article can be found online at: https://www.frontiersin.org/articles/10.3389/fimmu. 2018.02788/full\#supplementary-material

15. Alfen JS, Larghi P, Facciotti F, Gagliani N, Bosotti R, Paroni M, et al Intestinal IFN-gamma-producing type 1 regulatory $\mathrm{T}$ cells coexpress CCR5 and programmed cell death protein 1 and downregulate IL-10 in the inflamed guts of patients with inflammatory bowel disease. J Allergy Clin Immunol. (2018) 142:1537-47.e8. doi: 10.1016/j.jaci.2017.12.984

16. Ward ST, Li KK, Hepburn E, Weston CJ, Curbishley SM, Reynolds GM, et al. The effects of CCR5 inhibition on regulatory T-cell recruitment to colorectal cancer. Br J Cancer (2015) 112:319-28. doi: 10.1038/bjc.2014.572

17. Wei SC, Levine JH, Cogdill AP, Zhao Y, Anang NAS, Andrews MC, et al. Distinct cellular mechanisms underlie anti-CTLA-4 and anti-PD-1 checkpoint blockade. Cell (2017) 170:1120-33 e17. doi: 10.1016/j.cell.2017.07.024

18. Wherry EJ. T cell exhaustion. Nat Immunol. (2011) 12:492-9. doi: 10.1038/ni.2035

19. Kalathil SG, Lugade AA, Miller A, Iyer R, Thanavala Y. PD-1(+) and Foxp3(+) $\mathrm{T}$ cell reduction correlates with survival of HCC patients after sorafenib therapy. JCI Insight. (2016) 1:e86182. doi: 10.1172/jci.insight.86182

20. Rallon NI, Lopez M, Soriano V, Garcia-Samaniego J, Romero M, Labarga P, Garcia-Gasco P, et al. Level, phenotype and activation status of CD4+FoxP3 + regulatory $\mathrm{T}$ cells in patients chronically infected with human immunodeficiency virus and/or hepatitis C virus. Clin Exp Immunol. (2009) 155:35-43. doi: 10.1111/j.1365-2249.2008.03797.x

21. Wing K, Onishi Y, Prieto-Martin P, Yamaguchi T, Miyara M, Fehervari Z, et al. CTLA-4 control over Foxp3 + regulatory T cell function. Science (2008) 322:271-5. doi: 10.1126/science.1160062

22. Takahashi T, Tagami T, Yamazaki S, Uede T, Shimizu J, Sakaguchi $\mathrm{N}$, et al. Immunologic self-tolerance maintained by $\mathrm{CD} 25(+) \mathrm{CD} 4(+)$ regulatory $\mathrm{T}$ cells constitutively expressing cytotoxic $\mathrm{T}$ lymphocyteassociated antigen 4. J Exp Med. (2000) 192:303-10. doi: 10.1084/jem.19 2.2.303

23. Ishida Y, Agata Y, Shibahara K, Honjo T. Induced expression of PD-1, a novel member of the immunoglobulin gene superfamily, upon programmed cell death. EMBO J. (1992) 11:3887-95. doi: 10.1002/j.1460-2075.1992.tb05481.x

24. Freeman GJ, Long AJ, Iwai Y, Bourque K, Chernova T, Nishimura H, et al. Engagement of the PD-1 immunoinhibitory receptor by a novel B7 family member leads to negative regulation of lymphocyte activation. J Exp Med. (2000) 192:1027-34. doi: 10.1084/jem.192.7.1027

25. Keir ME, Butte MJ, Freeman GJ, Sharpe AH. PD-1 and its ligands in tolerance and immunity. Annu Rev Immunol. (2008) 26:677-704. doi: 10.1146/annurev.immunol.26.021607.090331

26. Parry RV, Chemnitz JM, Frauwirth KA, Lanfranco AR, Braunstein I, Kobayashi SV, et al. CTLA-4 and PD-1 receptors inhibit T-cell activation by distinct mechanisms. Mol Cell Biol. (2005) 25:9543-53. doi: 10.1128/MCB.25.21.9543-9553.2005

27. Hui E, Cheung J, Zhu J, Su X, Taylor MJ, Wallweber HA, et al. T cell costimulatory receptor CD28 is a primary target for PD-1-mediated inhibition. Science (2017) 355:1428-33. doi: 10.1126/science.aaf1292

28. Kamphorst AO, Wieland A, Nasti T, Yang S, Zhang R, Barber DL, et al. Rescue of exhausted CD8 T cells by PD-1-targeted therapies is CD28-dependent. Science (2017) 355:1423-7. doi: 10.1126/science.aaf0683 
29. Intlekofer AM, Thompson CB. At the bench: preclinical rationale for CTLA-4 and PD-1 blockade as cancer immunotherapy. J Leukoc Biol. (2013) 94:25-39. doi: 10.1189/jlb.1212621

30. Pardoll DM. The blockade of immune checkpoints in cancer immunotherapy. Nat Rev Cancer (2012) 12:252-64. doi: 10.1038/nrc3239

31. Chambers CA, Sullivan TJ, Allison JP. Lymphoproliferation in CTLA-4deficient mice is mediated by costimulation-dependent activation of CD4+ T cells. Immunity (1997) 7:885-95. doi: 10.1016/S1074-7613(00)80406-9

32. Chambers CA, Kuhns MS, Allison JP. Cytotoxic T lymphocyte antigen-4 (CTLA-4) regulates primary and secondary peptide-specific CD4(+) T cell responses. Proc Natl Acad Sci USA. (1999) 96:8603-8. doi: $10.1073 /$ pnas.96.15.8603

33. Kamphorst AO, Pillai RN, Yang S, Nasti TH, Akondy RS, Wieland A, et al. Proliferation of PD-1+ CD8 T cells in peripheral blood after PD-1-targeted therapy in lung cancer patients. Proc Natl Acad Sci USA. (2017) 114:4993-8. doi: 10.1073/pnas.1705327114

34. Vukmanovic-Stejic M, Zhang Y, Cook JE, Fletcher JM, McQuaid A, Masters JE, et al. Human $\mathrm{CD} 4{ }^{+} \mathrm{CD} 25^{\text {hi }}$ Foxp $3^{+}$regulatory T cells are derived by rapid turnover of memory populations in vivo. J Clin Invest. (2006) 116:2423-33. doi: 10.1172/JCI28941

35. Sanchez Rodriguez R, Pauli ML, Neuhaus IM, Yu SS, Arron ST, Harris HW, et al. Memory regulatory $\mathrm{T}$ cells reside in human skin. J Clin Invest. (2014) 124:1027-36. doi: 10.1172/JCI72932

36. Fainboim L, Navarrete C, Festenstein H. Precursor and effector phenotypes of activated human T lymphocytes. Nature (1980) 288:391-3. doi: $10.1038 / 288391 \mathrm{a} 0$

37. Rollins MR, Gibbons Johnson RM. CD80 Expressed by CD8(+) T Cells Contributes to PD-L1-Induced Apoptosis of Activated CD8(+) T Cells. J Immunol Res. (2017) 2017:7659462. doi: 10.1155/2017/7 659462

38. Chaudhry A, Rudra D, Treuting P, Samstein RM, Liang Y, Kas A, Rudensky AY. CD4+ regulatory $\mathrm{T}$ cells control $\mathrm{TH} 17$ responses in a Stat3-dependent manner. Science (2009) 326:986-91. doi: 10.1126/science.11 72702

39. Yu X, Harden K, Gonzalez LC, Francesco M, Chiang E, Irving B, et al. The surface protein TIGIT suppresses $\mathrm{T}$ cell activation by promoting the generation of mature immunoregulatory dendritic cells. Nat Immunol. (2009) 10:48-57. doi: 10.1038/ni.1674

40. Levin SD, Taft DW, Brandt CS, Bucher C, Howard ED, Chadwick EM, et al. Vstm3 is a member of the CD28 family and an important modulator of T-cell function. Eur J Immunol. (2011) 41:902-15. doi: 10.1002/eji.201041136

41. Joller N, Hafler JP, Brynedal B, Kassam N, Spoerl S, Levin SD, et al. Cutting edge: TIGIT has T cell-intrinsic inhibitory functions. J Immunol. (2011) 186:1338-42. doi: 10.4049/jimmunol.1003081

42. Lozano E, Dominguez-Villar M, Kuchroo V, Hafler DA. The TIGIT/CD226 axis regulates human $\mathrm{T}$ cell function. J Immunol. (2012) 188:3869-75. doi: 10.4049/jimmunol.1103627
43. Ferraro A, D’Alise AM, Raj T, Asinovski N, Phillips R, Ergun A, et al. Interindividual variation in human T regulatory cells. Proc Natl Acad Sci USA. (2014) 111:E1111-20. doi: 10.1073/pnas.1401343111

44. Duhen T, Duhen R, Lanzavecchia A, Sallusto F, Campbell DJ. Functionally distinct subsets of human FOXP3+ Treg cells that phenotypically mirror effector Th cells. Blood (2012) 119:4430-40. doi: 10.1182/blood-2011-11-392324

45. Hirahara K, Liu L, Clark RA, Yamanaka K, Fuhlbrigge RC, Kupper TS. The majority of human peripheral blood $\mathrm{CD} 4^{+} \mathrm{CD} 25^{\text {high }}$ Foxp $3^{+}$regulatory $\mathrm{T}$ cells bear functional skin-homing receptors. J Immunol. (2006) 177:4488-94. doi: 10.4049/jimmunol.177.7.4488

46. Sugiyama D, Nishikawa H, Maeda Y, Nishioka M, Tanemura A, Katayama I, et al. Anti-CCR4 mAb selectively depletes effector-type FoxP3+CD4+ regulatory $\mathrm{T}$ cells, evoking antitumor immune responses in humans. Proc Natl Acad Sci USA. (2013) 110:17945-50. doi: 10.1073/pnas.13167 96110

47. Crespo J, Sun H, Welling TH, Tian Z, Zou W. T cell anergy, exhaustion, senescence, and stemness in the tumor microenvironment. Curr Opin Immunol. (2013) 25:214-21. doi: 10.1016/j.coi.2012.12.003

48. Tsushima F, Yao S, Shin T, Flies A, Flies S, Xu H, et al. Interaction between B7 $\mathrm{H} 1$ and PD-1 determines initiation and reversal of T-cell anergy. Blood (2007) 110:180-5. doi: 10.1182/blood-2006-11-060087

49. Wherry EJ, Kurachi M. Molecular and cellular insights into T cell exhaustion. Nat Rev Immunol. (2015) 15:486-99. doi: 10.1038/nri3862

50. Wherry EJ, Blattman JN, Murali-Krishna K, van der Most R, Ahmed R. Viral persistence alters CD8 T-cell immunodominance and tissue distribution and results in distinct stages of functional impairment. J Virol. (2003) 77:4911-27. doi: 10.1128/JVI.77.8.4911-4927.2003

51. Paley MA, Kroy DC, Odorizzi PM, Johnnidis JB, Dolfi DV, Barnett BE, et al. Progenitor and terminal subsets of CD8 + T cells cooperate to contain chronic viral infection. Science (2012) 338:1220-5. doi: 10.1126/science.1229620

52. Johnston RJ, Comps-Agrar L, Hackney J, Yu X, Huseni M, Yang Y, et al. The immunoreceptor TIGIT regulates antitumor and antiviral CD8(+) T cell effector function. Cancer Cell. (2014) 26:923-37. doi: 10.1016/j.ccell.2014.10.018

Conflict of Interest Statement: The authors declare that the research was conducted in the absence of any commercial or financial relationships that could be construed as a potential conflict of interest.

Copyright (C) 2018 Machicote, Belén, Baz, Billordo and Fainboim. This is an openaccess article distributed under the terms of the Creative Commons Attribution License (CC BY). The use, distribution or reproduction in other forums is permitted, provided the original author(s) and the copyright owner(s) are credited and that the original publication in this journal is cited, in accordance with accepted academic practice. No use, distribution or reproduction is permitted which does not comply with these terms. 